\title{
Sub-Saharan Africa: A Survey of Gender Budgeting Efforts
}




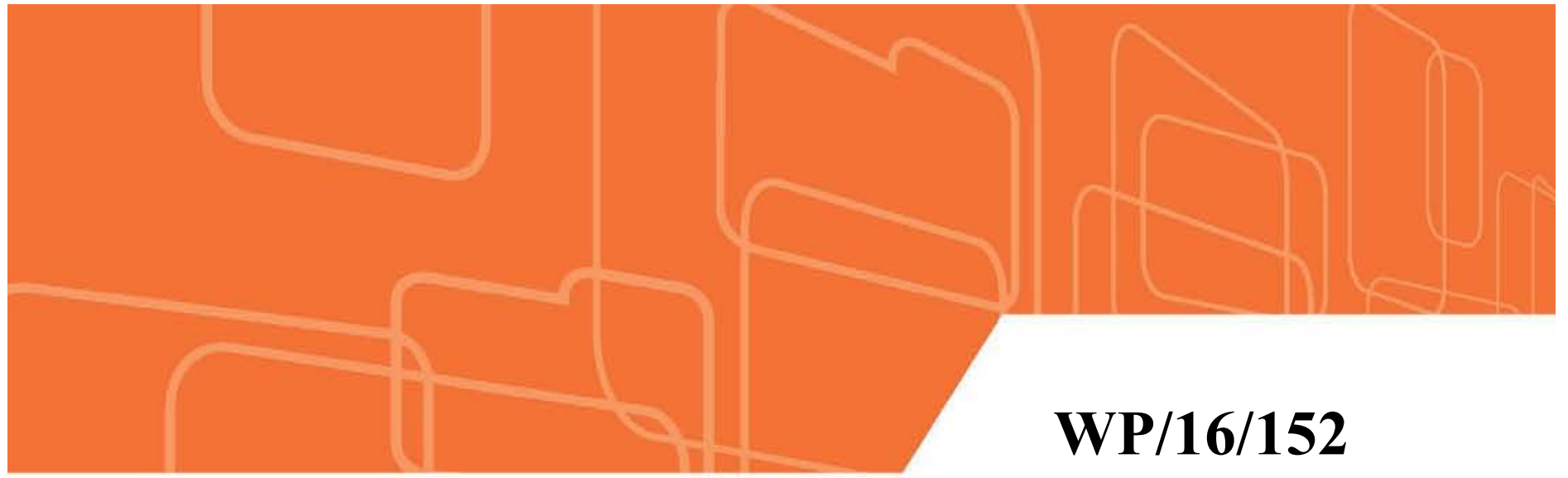

\title{
IMF Working Paper
}

Sub-Saharan Africa: A Survey of Gender Budgeting Efforts

\author{
By Janet G. Stotsky, Lisa Kolovich, and Suhaib Kebhaj
}

I N TER N A T I O N A L M O NETARY FU N D 


\title{
IMF Working Paper
}

Strategy, Policy, and Review and Research Departments

\section{Sub-Saharan Africa: A Survey of Gender Budgeting Efforts}

\author{
Prepared by Janet G. Stotsky, Lisa Kolovich, and Suhaib Kebhaj*
}

Authorized for distribution by Prakash Loungani and Catherine Pattillo

July 2016

\section{IMF Working Papers describe research in progress by the author(s) and are published to} elicit comments and to encourage debate. The views expressed in IMF Working Papers are those of the author(s) and do not necessarily represent the views of the IMF, its Executive Board, or IMF management.

\begin{abstract}
Gender budgeting is an initiative to use fiscal policy and administration to address gender inequality and women's advancement. A large number of sub-Saharan African countries have adopted gender budgeting. Two countries that have achieved notable success in their efforts are Uganda and Rwanda, both of which have integrated gender-oriented goals into budget policies, programs, and processes in fundamental ways. Other countries have made more limited progress in introducing gender budgeting into their budget-making. Leadership by the ministry of finance is critical for enduring effects, although nongovernmental organizations and parliamentary bodies in sub-Saharan Africa play an essential role in advocating for gender budgeting.
\end{abstract}

JEL Classification Numbers: H00, I3, J16

Keywords: Gender budgeting, fiscal policy and administration, gender inequality, subSaharan Africa

Authors’ Email Addresses: jstotsky@imf.org; 1kolovich@,imf.org; skebhaj@imf.org

\footnotetext{
* IMF. Our thanks to Virginia Alonso Albarran, Mark Blackden, Leslie Fisher, Margaret Kakande, Monique Newiak, Sheila Quinn, Cathy Pattillo, Tej Prakash, and Sandra Stotsky for helpful comments and to Sakina Shibuya and Asad Zaman for excellent research assistance. We gratefully acknowledge the assistance of Nalini Burn in identifying primary source materials and letting us draw upon her unpublished work on gender budgeting in sub-Saharan Africa. This paper is part of a research project on macroeconomic policy in lowincome countries and is supported by the United Kingdom's Department for International Development (DFID). It does not necessarily represent the views of the International Monetary Fund or of DFID.
} 


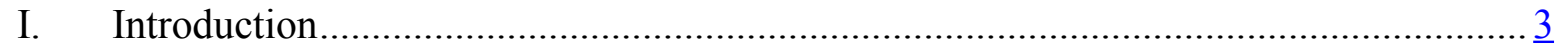

II. International and Regional Initiatives Supporting Gender Budgeting........................... $\underline{8}$

III. Countries with Prominent Gender Budgeting Efforts................................................ 10

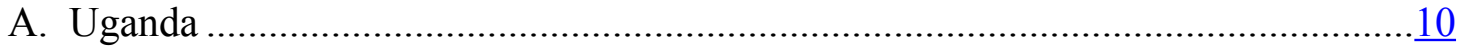

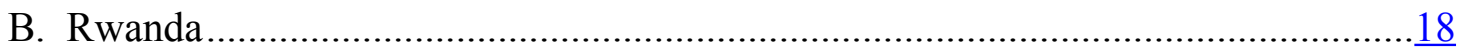

IV. Other Examples of Gender Budgeting in Sub-Saharan Africa ..................................25

V. Conclusions and Lessons for Improving Gender Budgeting in the Region ....................38

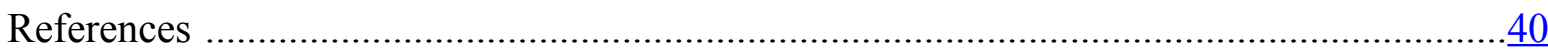

Figures

1. Sub-Saharan African Countries Included in this Review ............................................. $\underline{3}$

2. GDI, Time-Consistent Version …………………........................................... 6

3. Uganda: Trends in Gender Inequality in Uganda and a Comparator Country Group ...16

4. Uganda: Trends in School Enrollment..................................................................17

5. Uganda: Trends in Maternal Mortality and Health Expenditure ...................................17

6. Rwanda: Trends in Gender Inequality in Rwanda and a Comparator Country Group ..23

7. Rwanda: Trends in School Enrollment ....................................................................

8. Rwanda: Trends in Maternal Mortality and Health Expenditure....................................24

9. South Africa: Child Support Grant Coverage ..............................................................27

Tables

1. Sub-Saharan African Fiscal Indicators ......................................................................

2. Selected Indicators of Gender and Income Inequality ................................................ 7

3. Key Gender Indicators Collected by the Gender Monitoring Office .............................20

Boxes

1. Timeline for International and Regional Efforts Related to Gender Budgeting............. $\underline{9}$

2. Example of Gender Budgeting Statement on Land Planning and Management .............21

Appendix

A. Gender Budgeting in Sub-Saharan Africa Data Template............................................. 48 


\section{Introduction}

This paper reviews gender budgeting in sub-Saharan Africa and discusses examples of prominent gender budgeting efforts in the region, while noting salient features of other efforts. The countries under review are listed in Figure 1. The work here is part of a larger research project to survey worldwide practices in gender budgeting. ${ }^{1}$

\section{Figure 1. Sub-Saharan African Countries Included in this Review}

\begin{tabular}{|ccc|}
\hline Benin & Mauritius & South Africa \\
Cameroon & Mozambique & Tanzania \\
Ethiopia & Nigeria & Uganda \\
Gambia, The & Rwanda & Zimbabwe \\
Mali & Senegal & \\
\hline
\end{tabular}

Sub-Saharan African countries were among the earliest countries in the world to adopt gender budgeting - the use of fiscal policy and fiscal administration to advance gender equality and women's development. Following Australia's lead, South Africa was the first country in subSaharan Africa to embrace gender budgeting, spurring initiatives in Uganda and Tanzania, which were then followed by efforts in other countries in the region.

Our review of gender budgeting in sub-Saharan African found that Rwanda, Uganda, and South Africa have achieved some successes with gender budgeting, chiefly through changes in fiscal policies or budget-making procedures. However, it is difficult to link gender budgeting directly to these changes, given the complex environment for fiscal decisionmaking in these and other countries.

We found that, in the countries where gender budgeting seems to be most effective, Ministries of Finance are taking the lead. For example, Ministries of Finance in Rwanda and Uganda have mandated that other ministries or levels of government responsible for social welfare or women's development try to address gender gaps and women's needs in their budgets. Parliamentarians also played a catalytic role in these countries. ${ }^{2}$ In the countries with the most success in gender budgeting, there was a clear consensus by officials in government that gender budgeting would contribute not only to the well-being of females but to the welfare of society as a whole. Nongovernmental organizations and donors were helpful in generating research and applying pressure to support changes in fiscal policies in these countries. Donors have also provided financial support to gender budgeting efforts. We also found that a number of other countries in the region achieved some success with gender budgeting, though many efforts are only at initial stages and some efforts have been episodic.

Most sub-Saharan African countries continue to face many challenges in developing their economies, though in recent years, many have substantially improved macroeconomic and public financial management (IMF, 2013a). Most countries in the region are low income, though a few are middle income.

\footnotetext{
${ }^{1}$ See an overview of the conceptual goals of gender budgeting and a summary of results in Stotsky (2016).

${ }^{2}$ Byanyima (2003) also notes the importance of parliamentary participation.
} 


\section{Sub-Saharan African countries operate within constrained budgets}

Most sub-Saharan African budgets operate with limited revenue, on average below 25 percent of GDP (and some well below). Table 1 shows the average level of important fiscal aggregates for each country in the region. Many sub-Saharan African countries have limited ability to borrow on international financial markets and their budgets are stressed by global events (Berg et al., 2009). Public spending on education and health for all citizens is generally insufficient, even with substantial donor support in some countries. ${ }^{3}$ Weak or underdeveloped revenue bases constrain the ability of governments to fund their public services adequately (Keen and Mansour, 2009; Ebeke and Ehrhart, 2013). Sub-Saharan African countries must develop sustainable sources of revenue independent of donors to fund their public services adequately. Many sub-Saharan governments have undertaken reforms in public financial management in recent years, some with more success than others (Andrews, 2010). Public financial management reforms offer a natural opportunity for governments to integrate gender-oriented goals into program-based budgeting.

Most efforts at gender budgeting focus on spending allocations and emphasize the design of public programs. Although this emphasis on spending is largely appropriate, significant progress cannot be achieved without strengthening the revenue bases and ensuring that revenue policies contribute to gender equality goals. Discrimination against women in the personal income tax, once common in the region, is largely gone, but there is still scope to take into account implicit biases in indirect taxes in the design of tax systems (Stotsky, 1997; Grown and Valodia, 2010).

\section{Gender inequality in sub-Saharan Africa remains a significant problem}

Gender inequality in access to education and adequate health care and in paid employment remain pervasive in sub-Saharan Africa, though the region has seen improvement in recent years. Figure 2 shows the evolution of gender inequality over the last two decades in the region. Gender equality, as measured by the United Nations' Gender Development Index (GDI), has improved in almost every country over this period. ${ }^{4}$

Table 2 offers additional insights into gender inequality in the region. In education, subSaharan Africa is increasing female enrollment and closing gender gaps in primary and secondary education. However, there are stark differences in the ratios of female to male enrollment rates at the secondary level, across the region. Of the 45 sub-Saharan African countries listed in Table 1, only 12 have gross female enrollment rates above 50 percent of eligible students.

\footnotetext{
${ }^{3}$ African governments also have potential to improve the efficiency of public spending (Youhou, 2015).

${ }^{4}$ The GDI is a composite index that measures of gender inequality based on sex-disaggregated differences in schooling attainment, life expectancy, and income. The figures presented here correspond to our own variant of the index, measured on a time-consistent basis (Stotsky et al., 2016).
} 
Table 1. Sub-Saharan African Fiscal Indicators

\begin{tabular}{|c|c|c|c|c|c|c|c|}
\hline \multirow[b]{2}{*}{ Country } & \multicolumn{4}{|c|}{$\begin{array}{c}\text { Fiscal Aggregates }{ }^{1} \\
\text { (average 2011-2014; unless otherwise indicated) }^{2} \\
\text { (percent of GDP) }\end{array}$} & \multirow[b]{2}{*}{$\begin{array}{c}\text { Education }^{5} \\
\text { expenditure }\end{array}$} & \multirow[b]{2}{*}{$\begin{array}{c}\text { Health }^{5} \\
\text { expenditure }\end{array}$} & \multirow{2}{*}{$\begin{array}{c}\begin{array}{c}\text { Public Financial } \\
\text { Management }\end{array} \\
\begin{array}{c}\text { Public Expenditure and } \\
\text { Financial Accountability (PEFA), } \\
\text { overall score }^{6}\end{array}\end{array}$} \\
\hline & Total revenue & $\begin{array}{c}\text { Total } \\
\text { expenditure }\end{array}$ & $\begin{array}{c}\text { Overall }^{3} \\
\text { balance }\end{array}$ & $\begin{array}{c}\text { Gross }^{4} \\
\text { debt }\end{array}$ & & & \\
\hline Angola & 42.6 & 41.0 & 1.6 & 34.2 & 3.5 & 2.2 & n.a. ${ }^{7}$ \\
\hline Benin & 18.5 & 20.0 & -1.4 & 28.2 & 5.3 & 2.7 & 2.0 \\
\hline Botswana & 37.1 & 35.0 & 2.1 & 18.7 & n.a. & 3.3 & 2.6 \\
\hline Burkina Faso & 22.1 & 24.7 & -2.6 & 28.9 & 3.6 & 3.7 & 2.9 \\
\hline Burundi & 33.0 & 36.4 & -3.4 & 37.2 & 6.2 & 5.1 & 2.3 \\
\hline Cabo Verde & 24.4 & 32.9 & -8.5 & 95.4 & 5.3 & 3.3 & 2.8 \\
\hline Cameroon & 18.1 & 21.3 & -3.2 & 18.8 & 3.2 & 1.7 & n.a. \\
\hline Central African Republic & 13.4 & 14.8 & -1.4 & 47.5 & 1.2 & 2.0 & 1.7 \\
\hline Chad & 22.0 & 22.8 & -0.9 & 31.1 & 2.1 & 1.4 & n.a. \\
\hline Comoros & 29.8 & 24.3 & 5.5 & 32.3 & n.a. & 1.9 & 1.4 \\
\hline Congo, Dem. Rep. & 15.6 & 14.2 & 1.4 & 21.3 & 1.6 & 1.9 & n.a. \\
\hline Congo, Rep. & 43.6 & 40.3 & 3.3 & 38.2 & n.a. & 2.4 & 1.6 \\
\hline Cote d'Ivoire & 19.7 & 23.0 & -3.3 & 53.6 & n.a. & 1.8 & 1.6 \\
\hline Equatorial Guinea & 33.8 & 39.4 & -5.5 & 9.1 & n.a. & 2.8 & n.a. \\
\hline Eritrea & 15.5 & 30.7 & -15.3 & 128.9 & n.a. & 1.4 & n.a. \\
\hline Ethiopia & 15.7 & 17.5 & -1.8 & 37.1 & 4.7 & 3.0 & 2.7 \\
\hline Gabon & 28.8 & 26.7 & 2.1 & 24.7 & n.a. & 1.9 & 1.6 \\
\hline Gambia, The & 21.9 & 28.8 & -6.9 & 84.7 & 4.1 & 3.6 & n.a. \\
\hline Ghana & 18.2 & 29.1 & -10.9 & 54.2 & n.a. & 3.6 & 1.9 \\
\hline Guinea & 21.5 & 25.0 & -3.5 & 49.5 & 3.1 & 1.7 & n.a. \\
\hline Guinea-Bissau & 15.2 & 16.7 & -1.6 & 52.6 & n.a. & 1.6 & 1.1 \\
\hline Kenya & 19.6 & 25.2 & -5.6 & 43.3 & 6.6 & 1.8 & 2.4 \\
\hline Lesotho & 59.9 & 61.8 & -1.9 & 42.8 & n.a. & 9.0 & 1.9 \\
\hline Liberia & 28.2 & 31.0 & -2.8 & 29.4 & 2.8 & 3.6 & 1.9 \\
\hline Madagascar & 11.5 & 14.3 & -2.8 & 33.7 & 2.8 & 2.3 & 1.9 \\
\hline Malawi & 25.6 & 29.9 & -4.3 & 88.2 & 4.9 & 4.6 & 2.1 \\
\hline Mali & 16.5 & 18.9 & -2.4 & 26.6 & 4.6 & 2.7 & 2.8 \\
\hline Mauritius & 21.2 & 24.2 & -2.9 & 53.4 & 3.6 & 2.4 & 3.2 \\
\hline Mozambique & 29.4 & 34.9 & -5.5 & 46.5 & n.a. & 3.0 & 2.9 \\
\hline Namibia & 33.1 & 37.3 & -4.2 & 24.5 & n.a. & 4.9 & n.a. \\
\hline Niger & 21.7 & 25.0 & -3.3 & 28.7 & 4.1 & 2.3 & 2.1 \\
\hline Nigeria & 13.4 & 14.3 & -0.9 & 10.4 & n.a. & 1.1 & n.a. \\
\hline Rwanda & 24.5 & 26.9 & -2.4 & 24.7 & 4.9 & 6.4 & 3.0 \\
\hline Sao Tome and Principe & 32.5 & 39.0 & -6.5 & 72.6 & n.a. & 2.4 & 1.8 \\
\hline Senegal & 23.3 & 28.8 & -5.5 & 46.2 & 5.6 & 2.3 & 2.3 \\
\hline Seychelles & 39.3 & 36.7 & 2.6 & 74.3 & 3.6 & 3.6 & 2.6 \\
\hline Sierra Leone & 15.0 & 19.0 & -4.0 & 37.1 & 2.7 & 2.2 & 2.4 \\
\hline South Africa & 27.5 & 31.5 & -3.9 & 42.6 & 6.2 & 4.2 & 3.6 \\
\hline South Sudan & 22.3 & 27.9 & -5.6 & 9.5 & 0.7 & 0.7 & 1.7 \\
\hline Swaziland & 27.1 & 27.3 & -0.2 & 14.2 & 7.4 & 5.8 & 2.1 \\
\hline Tanzania & 15.4 & 19.1 & -3.7 & 30.8 & 6.2 & 2.8 & 2.4 \\
\hline Togo & 19.9 & 25.2 & -5.3 & 51.8 & 4.3 & 4.1 & 1.4 \\
\hline Uganda & 13.6 & 16.9 & -3.3 & 26.7 & 3.0 & 4.8 & 2.5 \\
\hline Zambia & 18.2 & 22.4 & -4.2 & 26.8 & n.a. & 2.6 & 2.2 \\
\hline Zimbabwe & 27.2 & 28.5 & -1.3 & 53.6 & 2.0 & n.a. & n.a. \\
\hline Regional average & 24.4 & 27.3 & -3.0 & 41.4 & 4.0 & 3.0 & 2.2 \\
\hline
\end{tabular}

Sources: World Economic Outlook (WEO), World Bank Development Indicators (WDI), and IMF staff calculations.

$1 /$ All figures except for health and education expenditure are drawn from the latest WEO publication, and the concept of government corresponds to that in the WEO. Please see the WEO for further details. Health and education expenditure are drawn from World Bank Development Indicators (WDI) and correspond to the general government concept.

$2 /$ The figures are based on the average over the number of years in this period for which data were available.

$3 /$ Corresponds to the concept of total revenue minus total expenditure.

$4 /$ Gross debt does not net out holdings of debt by other entities of the government.

$5 /$ The figures for education and health expenditure are based on 2010-2013 averages or the number of years for which data are available in this period. The 2013 data are the latest available.

6/ PEFA is a performance monitoring framework used to assess the public financial management systems in developing countries. It is an initiative jointly supported by the World Bank, IMF, European Commission, and other development and government institutions. The framework consists of 28 indicators with each indicator scored on a scale from A (highest) to D (lowest). PEFA scores reported above are an average of the 28 indicators and convert the four ordinal PEFA scores (A,B,C,D) to numerical scores $(4,3,2,1)$ with “+” score given 0.5 point. A higher PEFA score implies stronger administration of public finance. On a global basis, the lowest score is 1.1 and highest score is 3.6. Please see https://www.pefa.org/ for further details.

${ }^{7 /}$ Data are not available. 
Figure 2. GDI, Time-Consistent Version ${ }^{1}$

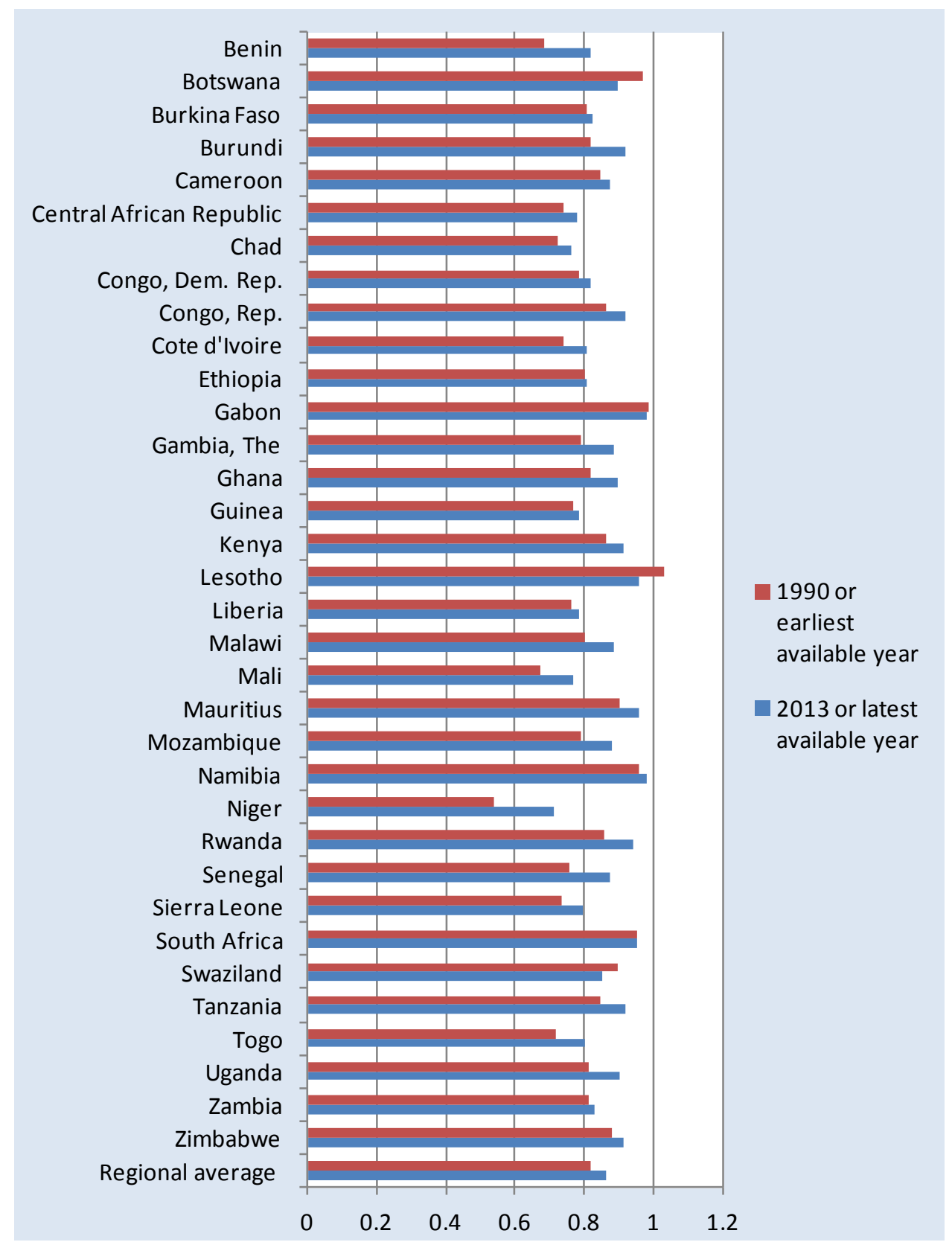

Source: Stotsky et al. (2016).

Note: The time-consistent GDI was not calculated for Angola, Cape Verde, Comoros, Equatorial Guinea, Eritrea, Guinea-Bissau, Madagascar, Nigeria, Sao Tome and Principe, Seychelles, and South Sudan because they lacked data used in the calculation of the index. $1 /$ The GDI generally ranges from 0 to 1 , where a higher number implies more equality. 
Table 2. Selected Indicators of Gender and Income Inequality

\begin{tabular}{|c|c|c|c|c|c|c|c|c|c|}
\hline \multirow[b]{2}{*}{ Country } & \multirow[t]{2}{*}{$\begin{array}{l}\text { GDI, time- } \\
\text { consis tent } \\
\quad(2013)\end{array}$} & \multirow[t]{2}{*}{$\begin{array}{c}\text { Gini } \\
\text { coefficie nt }^{1} \\
\text { (scale } 0-100)\end{array}$} & \multicolumn{2}{|c|}{$\begin{array}{c}\text { Gross secondary } \\
\text { enrollment }\end{array}$} & \multicolumn{2}{|c|}{$\begin{array}{c}\text { Labor force } \\
\text { participation rate } \\
\text { (ages 15-64) }\end{array}$} & \multirow[t]{2}{*}{$\begin{array}{l}\text { Mate rnal } \\
\text { mortality } \\
\text { ratio } \\
\text { (per 100,000) }\end{array}$} & \multirow[t]{2}{*}{$\begin{array}{l}\text { Legis lation } \\
\text { exists on } \\
\text { domestic } \\
\text { violence } \\
\end{array}$} & \multirow[t]{2}{*}{$\begin{array}{l}\text { Married men and } \\
\text { women have equal } \\
\text { owners hip rights } \\
\text { to property }\end{array}$} \\
\hline & & & $\begin{array}{l}\text { female to } \\
\text { male ratio }\end{array}$ & $\begin{array}{c}\text { Female } \\
\text { (percent) }\end{array}$ & $\begin{array}{l}\text { female to } \\
\text { male ratio }\end{array}$ & $\begin{array}{c}\text { Female } \\
\text { (percent) }\end{array}$ & & & \\
\hline Angola & n.a. ${ }^{2}$ & 42.7 & 0.65 & 24.8 & 0.83 & 64.5 & 477 & Yes & Yes \\
\hline Benin & 0.819 & 43.4 & 0.61 & 36.1 & 0.88 & 68.9 & 405 & Yes & Yes \\
\hline Botswana & 0.899 & 60.5 & 1.06 & 84.3 & 0.91 & 75.0 & 129 & Yes & Yes \\
\hline Burkina Faso & 0.824 & 39.8 & 0.81 & 23.2 & 0.88 & 79.5 & 371 & No & Yes \\
\hline Burundi & 0.919 & 33.4 & 0.73 & 24.2 & 1.02 & 84.4 & 712 & Yes & Yes \\
\hline Cape Verde & n.a. & 47.2 & 1.19 & 100.9 & 0.64 & 55.7 & 42 & n.a. & n.a. \\
\hline Cameroon & 0.878 & 42.8 & 0.86 & 46.4 & 0.85 & 65.4 & 596 & No & No \\
\hline Central African Rep. & 0.778 & 56.2 & 0.51 & 12.1 & 0.85 & 73.0 & 882 & n.a. & n.a. \\
\hline Chad & 0.764 & 43.3 & 0.46 & 14.3 & 0.82 & 64.6 & 856 & No & No \\
\hline Comoros & n.a. & 55.9 & 0.96 & 71.9 & 0.45 & 35.9 & 335 & n.a. & n.a. \\
\hline Congo, Dem. Rep. & 0.820 & 42.1 & 0.59 & 32.2 & 0.97 & 71.5 & 693 & No & No \\
\hline Congo, Rep. & 0.919 & 40.2 & 0.87 & 49.8 & 0.94 & 69.9 & 442 & No & No \\
\hline Cote d'Ivoire & 0.808 & 43.2 & 0.54 & 17.0 & 0.65 & 53.1 & 645 & No & No \\
\hline Equatorial Guinea & n.a. & n.a. & 0.72 & 23.6 & 0.87 & 82.1 & 342 & No & No \\
\hline Eritrea & n.a. & n.a. & 0.80 & 26.4 & 0.91 & 82.2 & 501 & n.a. & n.a. \\
\hline Ethiopia & 0.808 & 33.2 & 0.63 & 22.3 & 0.90 & 80.9 & 353 & Yes & Yes \\
\hline Gabon & 0.984 & 42.2 & 0.88 & 45.3 & 0.86 & 57.7 & 291 & No & No \\
\hline Gambia, The & 0.886 & 47.3 & 0.95 & 56.0 & 0.88 & 72.8 & 706 & n.a. & n.a. \\
\hline Ghana & 0.896 & 42.8 & 0.91 & 58.2 & 0.96 & 68.9 & 319 & Yes & Yes \\
\hline Guinea & 0.784 & 33.7 & 0.63 & 29.4 & 0.85 & 67.2 & 679 & No & Yes \\
\hline Guinea-Bissau & n.a. & 50.7 & 0.55 & 12.6 & 0.88 & 69.7 & 549 & n.a. & n.a. \\
\hline Kenya & 0.914 & 48.5 & 0.90 & 57.1 & 0.86 & 62.9 & 510 & No & Yes \\
\hline Lesotho & 0.961 & 54.2 & 1.40 & 62.3 & 0.81 & 60.3 & 487 & No & Yes \\
\hline Liberia & 0.787 & 36.5 & 0.82 & 40.6 & 0.91 & 59.5 & 725 & No & Yes \\
\hline Madagascar & n.a. & 40.6 & 0.95 & 37.1 & 0.97 & 88.2 & 353 & Yes & Yes \\
\hline Malawi & 0.889 & 46.1 & 0.90 & 32.4 & 1.05 & 84.5 & 634 & Yes & Yes \\
\hline Mali & 0.770 & 33.0 & 0.72 & 36.9 & 0.63 & 51.9 & 587 & No & Yes \\
\hline Mauritius & 0.957 & 35.8 & 1.04 & 97.8 & 0.61 & 49.0 & 53 & Yes & Yes \\
\hline Mozambique & 0.879 & 45.6 & 0.89 & 24.4 & 1.04 & 86.1 & 489 & Yes & Yes \\
\hline Namibia & 0.982 & 61.0 & 1.16 & 69.6 & 0.87 & 56.4 & 265 & Yes & Yes \\
\hline Niger & 0.714 & 31.5 & 0.67 & 12.8 & 0.45 & 40.6 & 553 & No & n.a. \\
\hline Nigeria & n.a. & 43.0 & 0.89 & 41.2 & 0.76 & 48.5 & 814 & Yes & Yes \\
\hline Rwanda & 0.940 & 51.3 & 1.07 & 32.8 & 1.02 & 88.0 & 290 & Yes & Yes \\
\hline Sao Tome and Principe & n.a. & 30.8 & 1.11 & 84.6 & 0.59 & 47.7 & 156 & Yes & Yes \\
\hline Senegal & 0.877 & 40.3 & 0.91 & 39.1 & 0.75 & 67.3 & 315 & Yes & Yes \\
\hline Seychelles & n.a. & 42.8 & 1.09 & 106.1 & n.a. & n.a. & n.a. & Yes & Yes \\
\hline Sierra Leone & 0.796 & 34.0 & 0.71 & 21.9 & 0.97 & 67.7 & 1360 & Yes & Yes \\
\hline South Africa & 0.952 & 63.4 & 1.03 & 103.5 & 0.77 & 48.9 & 138 & Yes & Yes \\
\hline South Sudan & n.a. & n.a. & n.a. & n.a. & n.a. & n.a. & 789 & No & Yes \\
\hline Swaziland & 0.854 & 51.5 & 0.97 & 59.1 & 0.62 & 45.4 & 389 & No & No \\
\hline Tanzania & 0.919 & 37.8 & 0.88 & 32.6 & 0.99 & 89.9 & 398 & No & Yes \\
\hline Togo & 0.801 & 46.0 & 0.53 & 30.4 & 1.00 & 82.2 & 368 & No & Yes \\
\hline Uganda & 0.901 & 42.4 & 0.83 & 25.1 & 0.96 & 76.6 & 343 & Yes & Yes \\
\hline Zambia & 0.833 & 55.6 & 0.59 & 15.0 & 0.85 & 73.3 & 224 & Yes & Yes \\
\hline Zimbabwe & 0.916 & n.a. & 0.90 & 36.1 & 0.93 & 84.8 & 443 & Yes & Yes \\
\hline Regional average & 0.865 & 44.2 & 0.84 & 43.4 & 0.84 & 67.5 & 477 & & \\
\hline
\end{tabular}


Conversely, compared with other regions in the developing world, sub-Saharan Africa has a high ratio of female to male labor force participation rates, even while women's participation remains lower than men's. However, women tend to be employed in the informal sector or subsistence agriculture and generally hold an inferior status in the job market compared to men.

Sub-Saharan Africa has made great strides in reducing maternal mortality. In the early 1990 s, the maternal mortality ratio in the region was over 1,000 deaths per 100,000 live births, almost double that in low-income and developing countries in the Middle East and Central Asia, Asia and the Pacific, or the Americas and Caribbean. The maternal mortality rate is now below 500 deaths per 100,000 live births for the region as a whole, but still excessively high. Countries that have had prolonged civil conflict are still struggling with higher rates of maternal mortality.

\section{The links between gender budgeting, gender inequality, and growth}

Gender budgeting efforts are based on two important premises. First, that addressing gender inequality and women's needs can have a positive influence on growth, and therefore, fiscal policies that are directed to these purposes are beneficial (Elborgh-Woytek, et al., 2013). Second, because fiscal policies influence economic and social outcomes, they can contribute to gender equality, in general. International conventions on gender equality argue in favor of both growth and fairness objectives.

There are many ways in which fiscal policies influence growth (IMF, 2015a). From a macroeconomic perspective, fiscal policies influence growth through their effect on budget stability and sustainability. At the microeconomic level, fiscal policies influence the composition and amounts of expenditures and revenues, and through them, human and physical capital accumulation and incentives to work, invest, and take risks, among other factors, all of which indirectly or directly contribute to economic growth. Fiscal policies interact with regulatory and structural policies to influence how industries and markets function, as well as to take externalities - positive and negative — into account. A growing number of studies have surveyed the relationship between gender equality, women's advancement, and economic growth (e.g., World Bank, 2011; Duflo, 2012; Bandiera and Natraj, 2013; Berik, van der Meulen Rodgers, and Seguino, 2009; Cuberes and Teignier, 2014; Kabeer and Natali, 2013; and Organization for Economic Cooperation and Development, 2012). Several of these surveys emphasize that gender inequality has an effect on growth, while growth has an effect on gender inequality.

\section{International and Regional Initiatives Supporting Gender Budgeting}

Several key international and regional agreements have played an important role in motivating and influencing gender budgeting efforts in sub-Saharan Africa. Box 1 summarizes several key agreements. 
Box 1. Timeline for Intemational and Regional Efforts Related to Gender Budgeting

1979: The UN adopts the
Convention on the Elimination of
All Forms of Discrimination
Against Women (CEDAW).

\begin{tabular}{|l|}
\hline 1996: The IMF and World Bank \\
launch the Heavily Indebted Poor \\
Countries debt relief initiative.
\end{tabular}

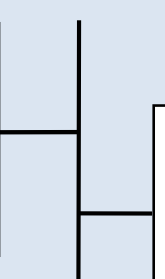

1995: The Beijing Platform for Action is adopted at the Fourth International Conference for Women.

2014: The African Union issues the Addis Ababa declaration that calls upon all member countries to adopt gender-sensitive planning and budgeting schemes.

2015: The UN adopts the

Sustainable Development Goals.

The UN General Assembly adopted the Convention on the Elimination of All Forms of Discrimination Against Women (CEDAW) in 1979 (Elson, 2006). As of 2014, all subSaharan African countries ${ }^{5}$ have ratified CEDAW and put in place mechanisms to monitor progress. The "Protocol to the African Charter on Human and People's Rights on the Rights of Women in Africa," adopted in 2003, by the Assembly of the African Union emphasizes the same theme (African Union, 2003).

The "Beijing Platform for Action," adopted in 1995 at the Fourth International Conference for Women, presented an agenda for women's empowerment (UN, 1995). Countries were asked to report every five years on progress. It explicitly called for gender budgeting:

- Paragraph 345: “... the integration of a gender perspective in budgetary decisions on policies and programmes, as well as the adequate financing of specific programmes for securing equality between women and men."

\footnotetext{
${ }^{5}$ We exclude Somalia and Sudan from this summary because they are not covered in this survey.
} 
- Paragraph 346: "Governments should make efforts to systematically review how women benefit from public sector expenditures; adjust budgets to ensure equality of access to public sector expenditures, both for enhancing productive capacity and meeting social needs...."

The introduction of the United Nations Millennium Development Goals in 2000 was another milestone for international support for women's development (UN, 2015). Goal 3 committed countries to the promotion of gender equality and empowerment of women, and specifically set as a target that countries equal enrollment for males and females at all levels of education. ${ }^{6}$ These goals were superseded by the Sustainable Development Goals, approved by the United Nations in 2015. Goal 5 is to "adopt and strengthen sound policies and enforceable legislation for the promotion of gender equality and the empowerment of all women and girls at all levels" (UN, 2015).

In a regional context, the Southern African Development Community introduced the Protocol on Gender and Development to come into force in 2012 (SADC, 2008). Article 15 of the Protocol stated that countries "shall ensure gender sensitive and responsive budgeting at the micro and macro levels, including tracking, monitoring and evaluation." This Protocol further recommended that countries should integrate women's unpaid work into national accounts and budgeting processes.

Likewise, the 2014 Addis Ababa Declaration of African ministers responsible for gender and women's affairs called upon member countries "to adopt gender-sensitive planning and budgeting schemes," and to strengthen domestic resource mobilization and allocation for women's and girls' rights (UNECA, 2015, p. 2). Only a minority of sub-Saharan African countries has a system of tracking in place for spending on gender equality and women's needs, and a public record of allocations (OECD/UNDP, 2014). ${ }^{7}$

\section{Countries with Prominent Gender Budgeting Efforts ${ }^{8}$}

\section{A. Uganda}

Uganda is a low-income, agricultural-based developing country that has made significant progress in improving macroeconomic control and strengthening growth (IMF, 2015b). Uganda's gender budgeting efforts have a primary objective to ensure that government ministries address gender issues through normal planning and budgeting processes. The country has achieved some success in addressing gender-oriented goals in education and health, and in strengthening justice, law, and order to attend to women's needs through budgeting initiatives at the national and local levels. ${ }^{9}$ These efforts reflect collaboration

\footnotetext{
${ }^{6}$ OECD (2014) reports that aid focused on the Millennium Development Goals increased substantially over time, tripling from US\$8 billion in 2002 to US\$24 billion in 2012. Most of this aid went to the education and health sectors, critical areas of need in sub-Saharan Africa.

${ }^{7}$ Holvoet and Inberg (2013) examine the effectiveness of donors in helping countries achieve gender-oriented education goals.

${ }^{8}$ Appendix A provides basic data on the prominent gender budgeting efforts in the region.

${ }^{9}$ Uganda government response to the IMF questionnaire, unpublished, 2015.
} 
among central ministries of government, nongovernmental organizations, and donors. However, the data suggest that Uganda still has a long way to go in achieving equality of women and men (Uganda Bureau of Statistics, 2014, xiv). Gender inequality is seen by the government as a significant constraint to higher growth (Ministry of Gender, Labour and Social Development, 2014, p. 14).

In the late 1990s, the Forum for Women in Democracy (FOWODE), a nongovernmental organization established by female members of parliament, led Uganda's first gender budgeting initiative (Budlender, 2002). FOWODE coordinated with the Parliamentary Budget Office and budget officers to advance gender budgeting; in addition, the group organized workshops for legislators and technocrats (Tanzarn, 2008, p. 16). FOWODE commissioned research at the national and district levels focusing on women's needs, and its three key sector-wide approaches centered on education, health, and agriculture. One of the goals of FOWODE's gender budgeting work was to improve maternal health, and under its sector-wide approach with the Ministry of Health, FOWODE worked to introduce "mama kits," which included items necessary for ensuring safe deliveries of babies in health facilities or at home (Tanzarn, 2008, p. 17).

In 1997, Uganda began implementing its Poverty Eradication Action Plan. The second revision, which came in 2000, and the third revision, in 2004, included a gender focus in the implementation strategies. The revisions highlighted infrastructure, security, health, education, agriculture, and water and sanitation as areas with the potential to reduce poverty among women (Ministry of Gender, Labour and Social Development, 2014, p. 14). As Kakande (2007) notes, though, the effort to incorporate gender into the Plans was not a priority.

During the development of the Education Sector Investment Plan, in 1998-2003, Uganda expanded access to education, seeking to equalize enrollment of boys and girls in primary and secondary school by 2015. It also sought to substantially increase female enrollment in tertiary education and in science and technology programs. The 2008/09 Ministry of Education and Sports' Policy Statement outlined specific measures to address gender inequities in education and argued for separate latrines for boys and girls in all newly constructed schools; revision of school curricula to identify and eliminate gender stereotypes; appointment of senior women to support adolescent girls and girls in post-conflict areas in the north; and affirmative action for hiring and promoting women (Tanzarn, 2008, p. 27).

Gender budgeting was formally adopted in 2004/05 when the Ministry of Finance, Planning, and Economic Development included gender budgeting in the Budget Call Circular.

Guidelines on how to address gender-oriented goals in the budget were attached as an annex for sector ministries and local governments. The initial focus was on Ministries of Education; Health; Agriculture; Justice, Law, and Order; Energy; and Water and Sanitation. ${ }^{10}$ The Ministry also produced sex-disaggregated data to inform discussions on the budget.

${ }^{10}$ Uganda government response to the IMF questionnaire, unpublished, 2015. 
The National Development Plan, covering 2010-2015, replaced the third Poverty Eradication Action Plan and focused squarely on growth, employment, and human development. One of the objectives was to promote gender equality and women's empowerment, and the Plan outlined three strategies along with more specific interventions, to meet this goal. Promoting and conducting gender budgeting and gender responsive monitoring and evaluation is included among the interventions (National Development Plan, 2013, p. 284). Throughout the Plan, the goal of improving gender equality typically is focused on programs and interventions aimed at women and girls. But we note that the Plan also acknowledges the important role that men play in achieving gender equality; one example relates to reproductive health and the availability of affordable, quality health services, which calls for promoting awareness among men, women, and communities about their roles and responsibilities for reproductive health issues.

A government review of the 2013 Plan concluded that progress had been made in addressing women's poverty through improvements in their access to water, health, and education services, noting that improved access to water and sanitation reduced the time spent by women and children in fetching water (Ministry of Gender, Labour and Social Development, 2014, p. 14). The Ministry laid out achievements in other areas including increased equality in primary schooling for girls and boys; gradual improvements in the number of births attended by skilled medical personnel and in health facilities; and a reduction in unmet needs for contraception and family planning, even while progress on reducing maternal mortality has stalled in recent years.

The budget call circular has been refined over the last few fiscal years to encourage sectors to adopt gender budgeting. The Ministry of Finance, Planning, and Economic Development observed that many sectors were providing blanket or general statements about how they planned to address gender inequality in the Budget Framework Papers (Dietl et al., 2014). Thus, the 2014/15 budget call circular required that sectors submit specific actions to address gender inequality through the budget. The $2016 / 17$ budget call circular ${ }^{11}$ reiterates this point and provides separate annexes with instructions on how sectors are to report on their plans. Ministries, departments, local governments, and agencies are asked to demonstrate how they are promoting gender equality and related objectives in the Sustainable Development Goals. In addition, the budget call circular directs ministries, departments, agencies, and local government to identify targets related to gender equality and measure progress towards these goals by collecting data disaggregated by sex, age, disability, and geographic location.

The Joint Programme on Gender Equality-Uganda, led by UN Women and funded by the United Kingdom's Department for International Development, was intended to bring together key international and local stakeholders advocating for gender equality to support the government of Uganda in attaining its development goals (Joint Programme on Gender Equality, 2014). It points to some achievements on gender-related fiscal policies in recent

\footnotetext{
${ }^{11}$ Uganda 2016/17 budget call circular at http://budget.go.ug/budget/sites/default/files/Budget $\% 20$ Call\%20Circular\%20on\%20Preparation\%20of\%20the $\% 20$ Budget $\% 20$ Framework $\% 20$ Papers $\% 20$ and $\% 20$ Preliminary $\% 20$ Budget $\% 20$ Estimates $\% 20$ for $\% 20 \mathrm{FY} \% 2020$ 16-17.pdf.
} 
years. These measures included Parliament's decision to eliminate the kerosene tax in fiscal year 2014/15, even though this measure was ultimately revoked by the President. Similarly, Parliament removed the 18 percent value added tax (VAT) on agricultural inputs and equipment for fiscal year 2014/15 benefiting farmers, the majority of whom are women (UN Joint Programme, 2014, p. 20). In addition, the Uganda Bureau of Statistics compiled documentation on the types of sex-disaggregated data collected by various ministries. ${ }^{12}$ The United Kingdom's Department for International Development's final report on the project assigned Uganda an "A" grade for its achievements under the program, specifically citing Uganda's progress on increasing girls' education and addressing violence against women (DFID, 2015).

The 2015/16 budget speech outlines specific measures on the country's plans to improve women's health. ${ }^{13}$

- "Government will directly seek to address the health of mothers and children. Providing comprehensive antenatal care and malaria prevention for pregnant women, in addition to HIV voluntary counseling and testing services and nutritional supplements, will go a long way in this quest."

- The government "[i]ncreased the proportion of pregnant women living with HIV accessing Anti-Retro Viral treatment (ARVs) from 33 percent in 2007 to 87 percent in 2014 as a result of increased testing for HIV in pregnant women from 30 percent in 2008 to 95 percent in 2014."

The Ministry of Gender, Labour and Social Development has also outlined a number of activities, most of which intersect with the budget or efforts to strengthen public financial management:

- Initiating a Uganda Women's Entrepreneurship Program aimed at improving access to financial services for women and equipping them with skills for expanding their enterprises, improving value added, and marketing their products and services. The program will initially be implemented over a period of five years starting from fiscal year $2015 / 2016$.

- Introducing a Gender and Equity Compliance Certificate into the Public Finance Management Act of 2015. The Act calls upon all ministries, departments, and agencies to ensure that their budget frameworks and Ministerial Policy statements address genderoriented goals, and the certificate would be issued to reflect this.

- Instituting capacity building for senior government officials in gender budgeting. Institutions of higher learning are including these courses in their curricula.

\footnotetext{
${ }^{12}$ The Bureau of Statistics developed the "Compendium of Concepts and Definitions on Gender Statistics," available at http://www.ubos.org/onlinefiles/uploads/ubos/gender/Compendium\%20\%20of\%20Concepts\%20and\%20Definit ions $\% 20$ on\%20Gender\%20Statistics.pdf. The Compendium shows that sex-disaggregated data are available for more than 20 key topics such as education, water use, poverty, crime, and labor force participation.

${ }^{13}$ The Ministry of Finance, Planning, and Economic Development 2015/16 Budget Speech "Maintaining Infrastructure Investment and Promoting Excellence in Public Services Delivery" at http://budget.go.ug/budget/sites/default/files/National\%20Budget\%20docs/FY\%202015_16\%20Budget\%20Spe ech_11th\%20June\%202015.pdf.
} 
- Requiring that all accounting officers deliver on gender equality and women's empowerment as one of their own indicators of performance on the job.

- Issuing gender mainstreaming guidelines and establishing a national coordination mechanism aimed at ensuring systematic integration of gender equality and women's empowerment issues in development plans, policies, programs, and the budget.

- Establishing a National Gender Multi-Sectoral Framework for monitoring implementation and reporting on international and regional Gender Equality and Women's Empowerment goals.

- Developing, in institutions of government, sector-specific gender policies and strategies, and establishing Gender Working Technical Committees to spearhead the gender agenda.

- Conducting, through the Ministry of Local Government, an annual assessment of local government plans, programs, and budgets for gender responsiveness. One of the key indicators under the national assessment is the allocation of resources for the gender equality and women's empowerment goals. The well-performing local governments are given incentives in terms of increased resource allocation under unconditional grants from the central government.

- Initiating a Value for Money Audit from a gender perspective by the Auditor General's Office. The office conducts audits for sectors and local governments on an annual basis for gender responsiveness.

In addition to the headway made at the national level, Uganda adopted local level gender budgeting initiatives. The Ministry of Local Government established guidelines that encouraged local governments to use gender-aware budget statements and sex-disaggregated beneficiary assessments (Ministry of Gender, Labour, and Social Development/Ministry of Local Government, 2005, p. 11). Local governments were instructed to check whether their investment plans reflected gender-oriented goals and if the budget had allocated sufficient funds to implement the plans (Lakwo, 2009, p. 109).

Under the UN Joint Programme, the government developed gender-oriented performance indicators for local governments and assigned them out to all 133 local governments in Uganda. As of fiscal year 2014/15, these indicators provide a measure of local government performance in planning and using resources for gender equality, and ties central government grants to good performance. Local governments have made progress in keeping girls in school, responding to violence against women, and improving water supply (UN Joint Programme, 2014, p. 10).

Local governments included gender-oriented concerns in their development plans as well. One example is the Lyantonde District Local Government Five Year District Development Plan for FY 2011/12 - 2015/16, ${ }^{14}$ which offers a sex-disaggregated analysis. For example, a table on resource ownership shows that men own and control household resources. The plan also offers insight into the sex imbalance in time spent on unpaid work using a daily representative schedule for both sexes in rural areas.

\footnotetext{
${ }^{14}$ Lyantonde District Local Government Five Year District Development Plan at http://npa.ug/wpcontent/themes/npatheme/documents/Central/LYANTONDE\%20DDP.pdf.
} 
Local level gender budgeting was introduced in Northern Uganda in 2012 under a one-year pilot program through a collaboration of the UNDP, the Government of Japan, the Uganda Ministry of Gender, Labour, and Social Development, the Parliamentary Budget Office, and others. Northern Uganda suffered through more than 20 years of conflict. The UNDP observed that not only was gender inequality higher in Northern Uganda than in other parts of the country, but the gaps were widening (UNDP, 2011). An evaluation conducted at the end of the pilot found that the project had resulted in some additional allocations of money for education and health programs related to women and raised awareness on the importance of addressing gender-oriented concerns through the budget (Mugisha Baine, 2013).

Uganda has also instituted something called village budget clubs. FOWODE has been actively involved in these clubs, which offer a forum for local citizens to monitor the use of public resources and hold government accountable (Dietl et al., 2014). One example of these clubs can be found in Kabale, where the club consists of both males and females. The citizens decide on priority sectors for government spending programs and monitor the government's performance on program delivery. Interviews with the Kabale club revealed that the club's monitoring efforts uncovered areas for improvement, such as incomplete "mama kits" or a lack of emphasis on indigenous crops in government programs. Village budget clubs have provided women with a platform to advocate for maternal health, infrastructure, education, and other issues of importance.

Figure 3 presents some comparisons of Uganda's progress in key indicators of women's development, including education, health, and labor force participation, and two overall indices of gender equality, our own time-consistent variants of the UNDP's Gender Development Index and Gender Inequality Index. We compare Uganda's progress to that of a group of sub-Saharan African countries that are similar to Uganda in that they are low income and do not rely heavily on resource-based industries. The figure suggests that Uganda moved from lagging its comparators in 1990 in all indicators of enrollment in education and maternal mortality ratio to exceeding this group except in secondary education enrollment, in the latest period of data (which varies, depending on the data availability). Progress on labor force participation is less clear. The female to male ratio fell, in contrast to the comparator group, although we do not have a measure of the quality of women's employment compared to men's. The Gender Development Index improved more than the comparator group's index, while the Gender Inequality Index moved about the same.

Figures 4 and 5 look at specific indicators of education and health before and after the introduction of gender budgeting (marked by a vertical line in the figures). Uganda continued to make progress on equalizing the number of boys and girls enrolled in primary school, secondary, and tertiary education, measured in percent of the relevant population, following the introduction of gender budgeting, though as with all these comparisons, we cannot necessarily infer causality. There was some evidence of an increased rate of change, following the introduction of gender budgeting. However, females still have lower enrollment in secondary and tertiary education, in the latest data. The decline in the maternal mortality ratio that began before gender budgeting was in place continued in the years following. 
Figure 3. Trends in Gender Inequality in Uganda and a Comparator Country Group

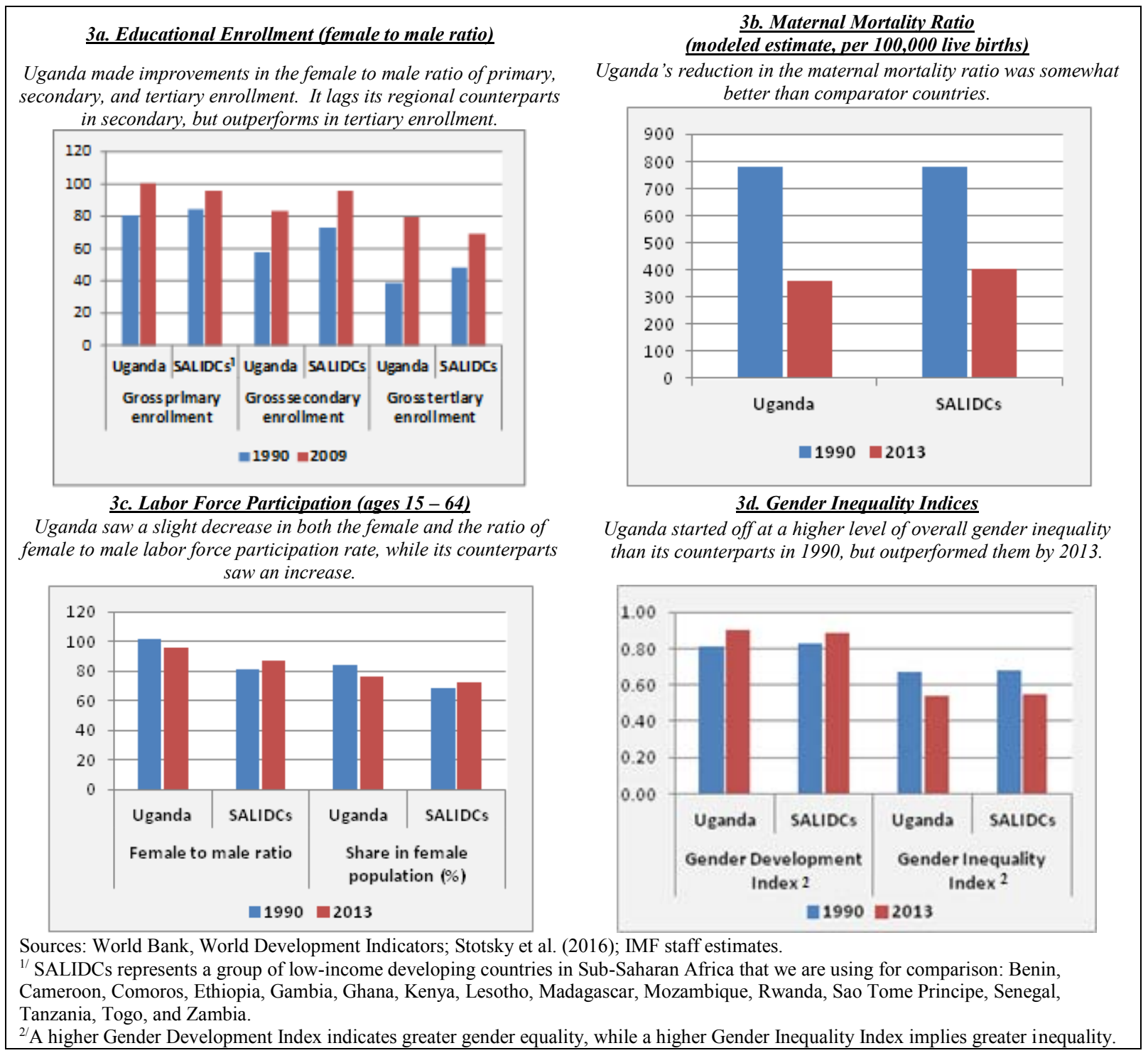

\section{Lessons from Uganda}

The Ugandan experience suggests that governments can address gender-oriented goals through the budget by setting clear and well thought-out priorities in different sectors of the economy. The use of Uganda's budget at the national and subnational levels to address gender-oriented gaps and women's needs in education and health demonstrates the positive role that government plays, even though progress remains slow. The introduction of the Certificate on Gender and Equity Compliance to monitor sectoral compliance with genderoriented goals and the linking of intergovernmental transfers to local governments to programs on gender equity are innovative and suggest a genuine commitment to achieving gender equity and addressing women's needs through the budget. Uganda's efforts would benefit from more formal assessment as a guide to strengthening its efforts. 
Figure 4. Uganda: Trends in School Enrollment (female to male ratio)

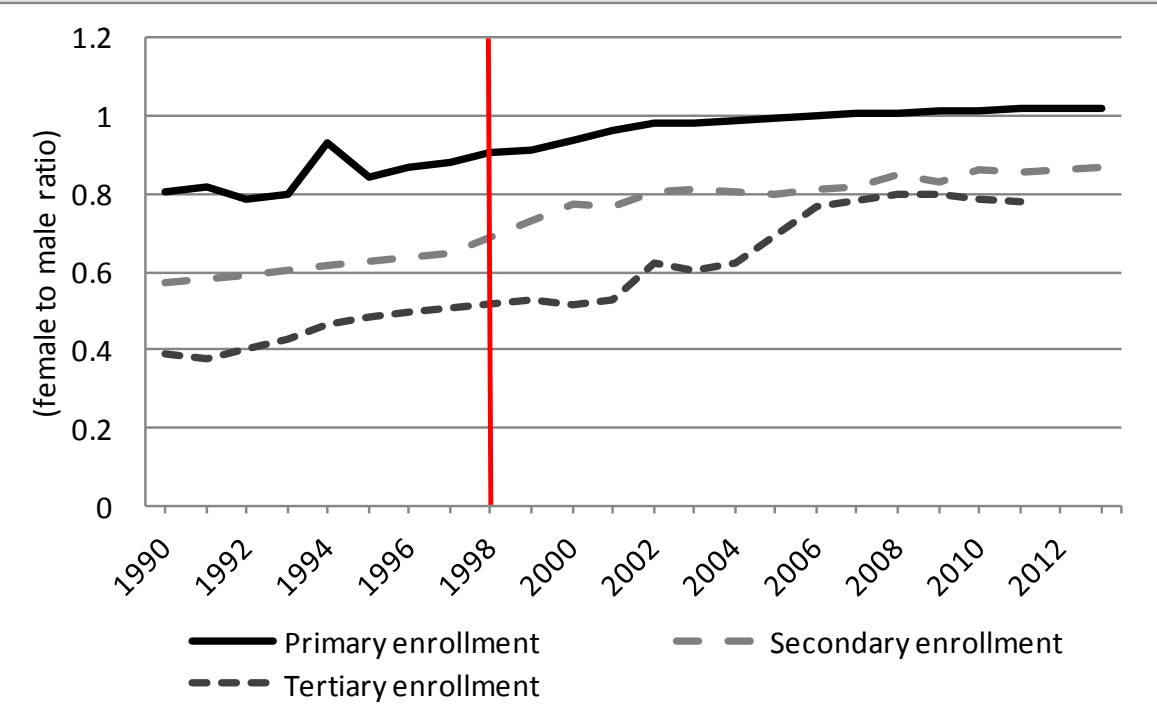

Sources: World Bank, World Development Indicators; IMF staff estimates.

Note: The vertical line indicates the start of gender budgeting in the education sector marked by the start of the Education Sector Investment plan in 1998.

Figure 5. Uganda: Trends in Maternal Mortality and Health Expenditure

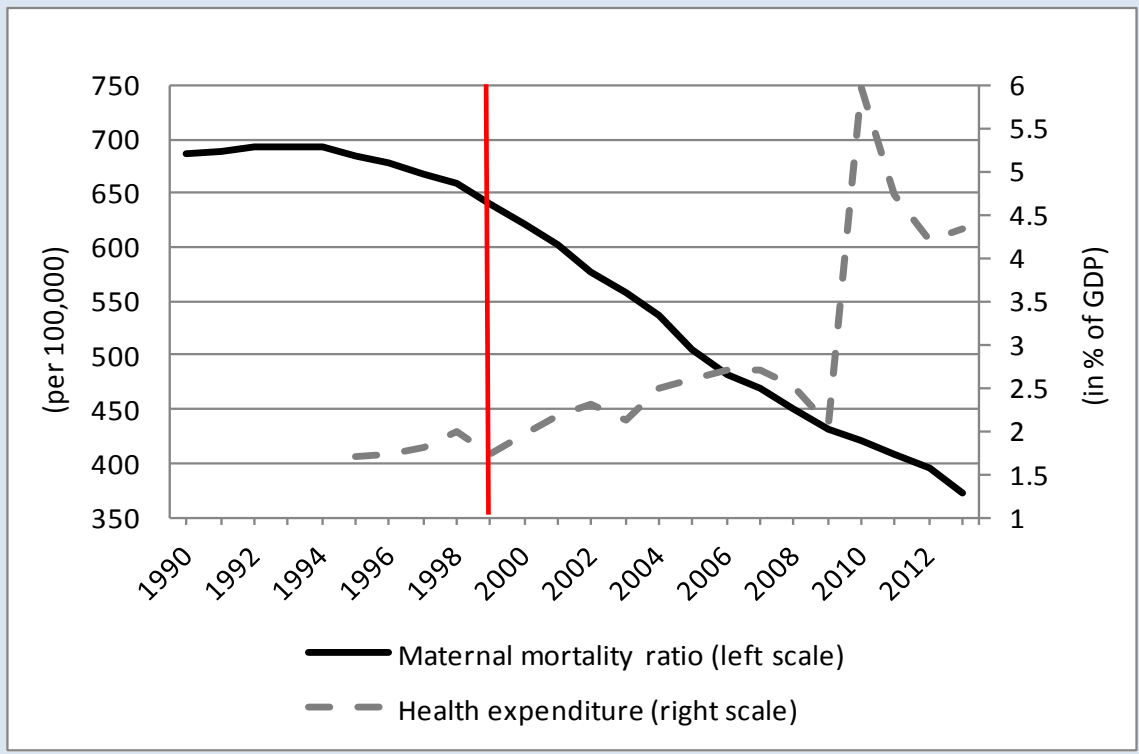

Sources: World Bank, World Development Indicators; and IMF staff estimates.

Note: The vertical line indicates the start of gender budgeting in the health sector marked by the start of FOWODE's initiative to improve maternal health in 1999. 


\section{B. Rwanda}

Rwanda is a low-income, agricultural-based developing country in Africa that has made impressive progress in rebuilding after civil conflict in the 1990s (IMF, 2014b). It has enjoyed high growth and macroeconomic stability in recent years. Budgeting to address gender equality and women's needs is embedded in the framework for developing a national budget. A recently enacted Organic Budget Law makes it mandatory for the government to include gender budget statements as part of the documentation submitted in the budget process. Monitoring takes place to ensure that all agencies of the government adhere to key features of the budget. Although it has made significant progress in closing gender gaps, women still remain at a disadvantage in key areas, including economic empowerment.

The Constitution of 2003 includes equal rights for women and men and mandates at least 30 percent women in all decision-making positions. Women constitute about two-thirds of the lower house of parliament, and are well represented in judiciary and cabinet positions, and as provincial governors, district council members, and mayors in charge of social affairs. The Constitution also provides the basis for gender-responsive laws across a variety of areas including in the areas of inheritance, land, and property rights, and protection against genderbased violence. To address gender inequality and protect women's rights, Rwanda established a Ministry of Gender and Family Promotion and a Gender Monitoring Office, and a national women's council.

Rwanda's first efforts at gender budgeting dates back to 2002, with its first initiative led by the Ministry of Gender and Family Promotion in collaboration with the Ministry of Finance and with support of the United Kingdom's Department for International Development (Ministry of Finance and Economic Planning, 2011). During this initiative, the government developed gender budget statements to be incorporated into program budgets. However, this early attempt foundered. In the government's view, the first initiative suffered in that the Ministry of Finance was not the lead on this effort, and there was an overreliance on outside experts and insufficient building of local capacity.

A second initiative was undertaken in 2008-2010, this time led by the Ministry of Finance, with support from UNIFEM, the United Nations entity responsible for women's issues (now UN Women). This initiative was premised on the view that every ministry was responsible for ensuring that women's needs were integrated into its areas of responsibility (Ministry of Finance and Economic Planning, 2011, p. 2). The Ministry of Gender and Family Promotion and the Gender Monitoring Office were responsible for oversight and support. The initiative also aimed to avoid over reliance on external consultants, instead trying to develop local capacity of staff. The authorities saw this initiative as part of a process of public financial management reform taking place at that time to move Rwanda's budget from an "accounting exercise" to program budgeting. It was also intended to be rolled out within local governments as well, in view of the importance of local governments in delivering basic public services. Although local governments in Rwanda lack a strong tax base for raising their own revenues, they do have the authority to adjust budgetary programs to address gender gaps and women's needs (Ministry of Finance and Economic Planning, 2011, p. 5). 
Underlying this initiative was a National Gender Policy that placed an emphasis on gender budgeting. "Budgeting is the condition sine qua non of success of implementation of the National Gender Policy. The Policy will not succeed unless adequate resources are allocated to programmes and activities related to it" (National Gender Policy, paragraph 3.3.6, quoted in Ministry of Finance and Economic Planning, 2011, p. 6).

The key objectives in the first phase were to sensitize planning and budgeting officers, train a core technical team, and establish sex-disaggregated data collection and monitoring at the national level. Initially, the government chose four sectors as pilots - health, education, agriculture, and infrastructure - because together they account for a substantial share of the budget and the government wished to demonstrate that gender-oriented goals were relevant beyond the social sector (Ministry of Finance and Economic Planning, 2011, p. 14). The focus was on both recurrent and capital spending, in line with the program budgeting being put in place. Because of the government's Economic Development and Poverty Reduction Strategy, the greatest priority was accorded to addressing the needs of the poor, taking account of the intersection of gender and poverty.

The key instrument for accountability was a Gender Budget Statement, a mechanism through which the government agencies could report to parliament. Ministries and agencies were required to submit the statements to the Ministry of Finance and although budget allocations were not dependent on them, they could lead to additions or changes in activities to "make them more gender-sensitive," leaving some scope for influencing budget allocations.

Agencies were also required to include an analysis of gender-oriented goals in their Strategic Issues Papers for program discussions. Budget agencies were also asked to report on the differences in civil service employment with respect to sex and level in the civil service.

A second phase, beginning in 2009, was intended to ensure implementation of the initiative in the four pilot areas and in local governments. It sought to build a system of monitoring and evaluation of targets, collect sex-disaggregated data, and develop indicators on genderoriented goals for each sector. In 2011, the Gender Monitoring Office published a study of key gender indicators in four sectors: Governance, Agriculture, Infrastructure, and the private sector (Gender Monitoring Office, 2011). Table 3 highlights some of the data collected.

One important accomplishment in this phase of the initiative was that the Ministry of Finance submitted the national budget in 2010/2011 with Gender Budget Statements of the four pilot sectors, following the issuance of the first budget call circular (Ministry of Finance and Economic Planning, 2011). The call circular made the submission of Gender Budget Statements mandatory in the pilot sectors, but also required other sectors to demonstrate that gender had been integrated into budget submissions. It asked sectors to follow the multi-step approach used in gender budgeting elsewhere (i.e., an analysis of the problems and their policy implications; an assessment of how these policies could be incorporated into the budget; monitoring of execution and achievement of outputs; and evaluation of outcomes). 
Table 3. Key Gender Indicators Collected by the Gender Monitoring Office

\begin{tabular}{|c|c|c|c|}
\hline & Indicator & Percent Male & Percent Female \\
\hline \multicolumn{4}{|c|}{ Government Sector } \\
\hline & $\begin{array}{l}\text { Percentage of men and women on boards of directors in } \\
\text { public institutions }\end{array}$ & 73.2 & 26.8 \\
\hline & $\begin{array}{l}\text { Percentage of men and women in the high commissariat of } \\
\text { the police }\end{array}$ & 81.0 & 19.0 \\
\hline & Percentage of men and women ministers & 72.7 & 27.2 \\
\hline & Percentage of men and women mayors of districts & 90.0 & 10.0 \\
\hline & Percentage of men and women senators & 65.4 & 34.6 \\
\hline & $\begin{array}{l}\text { Percentage of men and women judges at the Supreme } \\
\text { Court }\end{array}$ & 57.0 & 43.0 \\
\hline & $\begin{array}{l}\text { Percentage of men and women members on boards of } \\
\text { directors of civil society organizations }\end{array}$ & 86.7 & 13.3 \\
\hline \multicolumn{4}{|c|}{ Agriculture Sector } \\
\hline & Staff in agriculture institutions & 66.0 & 34.0 \\
\hline & Agricultural credit beneficiaries & 64.0 & 36.0 \\
\hline \multicolumn{4}{|c|}{ Infrastructure Sector } \\
\hline & Persons employed within ICT companies & 71.1 & 28.9 \\
\hline & Number of persons employed in the transport sector & 71.6 & 28.4 \\
\hline & Number of persons accessing jobs in public infrastructure & 74.6 & 25.4 \\
\hline & Persons studying sciences and technology & 67.0 & 33.0 \\
\hline \multicolumn{4}{|c|}{ Private Sector } \\
\hline & Percentage of employees & 45.6 & 54.4 \\
\hline & $\begin{array}{l}\text { Number and percentage of private companies by gender of } \\
\text { owners }\end{array}$ & & \\
\hline & a. $\quad$ Agriculture & 85.7 & 14.3 \\
\hline & b. $\quad$ Mining & 93.2 & 6.8 \\
\hline & c. Tourism & 71.4 & 28.6 \\
\hline & d. Manufacturing & 64.0 & 35.5 \\
\hline
\end{tabular}

Source: Gender Monitoring Office, 2011.

The addendum to the 2010/2011 national budget contained the Gender Budget Statements of the ministries in the four pilot areas. Agencies were asked to:

- select output by sub-program, and describe the problem, focusing on gender-oriented aspects, if they were present;

- identify which outputs need to be achieved to address gender- or women-related needs, taken from the medium term expenditure framework structure;

- identify which activities the ministry and agencies would need to carry out to achieve the identified output;

- specify indicators to measure each output, and where available, in terms of sexdisaggregated data; and

- indicate the allocated budget for the sub-program and where applicable the budget for the gender-oriented activities.

The requirement of consistency between activities and program budgeting is a strength of the initiative. An extract from a local government Gender Budget Statement on land planning and management is given in Box 2 (Ministry of Finance and Economic Planning, 2011, p. 23). 


\section{Box 2. Example of Gender Budgeting Statement on Land Planning and Management}

\section{PROGRAMME: PLANNING, ADMINISTRATION AND MANAGEMENT OF LAND SUB-PROGRAMME: PLANNING AND MANAGEMENT OF LAND}

\begin{tabular}{|c|c|c|c|c|}
\hline GENDER ANALYSIS & OUTPUT & ACTIVITIES & INDICATORS & $\begin{array}{l}\text { BUDGET } \\
\text { (RFW) }\end{array}$ \\
\hline $\begin{array}{l}\text { The law regulating land } \\
\text { tenure in Rwanda gives } \\
\text { women the right to } \\
\text { administer and manage } \\
\text { land as a precious } \\
\text { family heritage. Never- } \\
\text { theless, many women } \\
\text { are unaware of this } \\
\text { right and are denied the } \\
\text { right to manage land, } \\
\text { and many of them do } \\
\text { not benefit from the } \\
\text { revenues from sale of } \\
\text { the property of their } \\
\text { husbands. These } \\
\text { revenues instead benefit } \\
\text { the husbands who use } \\
\text { the money as they wish. }\end{array}$ & $\begin{array}{l}\text { From now on, so as } \\
\text { to promote the rights } \\
\text { of women in respect } \\
\text { of property in } \\
\text { Karongi District, } \\
\text { property will be } \\
\text { registered in the } \\
\text { name of both } \\
\text { spouses- husband } \\
\text { and wife. }\end{array}$ & $\begin{array}{l}\text { Register all } \\
\text { landholdings }\end{array}$ & $\begin{array}{l}\text { All landholdings } \\
\text { in the District are } \\
\text { registered in the } \\
\text { name of husbands } \\
\text { and their wives. }\end{array}$ & $10,549,095$ \\
\hline
\end{tabular}

From fiscal year 2011/2012, the central level made Gender Budget Statements mandatory for all ministries. For fiscal year 2013/14, the Gender Monitoring Office determined that all districts and almost all ministries complied with the Gender Budget Statement requirement (Gender Monitoring Office, 2014).

In 2013, the Organic Budget Law, spearheaded by the Ministry of Finance and Economic Planning, formally institutionalized gender budgeting (Republic of Rwanda, 2014, p. 10). ${ }^{15}$ Article 4 includes achieving gender-oriented goals in the budget as one of six key principles. Article 32 of the law requires that the budget framework paper contain Gender Budgeting Statements, and Article 68 mandates activity reports of public entities to specify plans for achieving gender-oriented objectives (Organic Budget Law No. 12/2013/OL). In its 2013/2014 report, the Gender Monitoring Office indicates that implementation of gender budgeting had scope for significant improvements. It assessed the degree of adherence of Gender Budget Statements to their goals. Most ministries and districts respected the criteria on sub-program selection for inclusion, but relatively few provided an appropriate analysis of the situation, backed by sex-disaggregated data. In addition, relatively few of the Gender Budget Statements properly linked their analysis to activities, outputs, and indicators.

Rwanda also implemented gender budgeting at the local government level. It asked governments to divide services into those that have a specific gender-oriented goal and those that do not. The Gender Monitoring Office found that there is scope for improving the process of identifying indicators, and tracking and monitoring outcomes. It also noted that

\footnotetext{
${ }^{15}$ It drew upon Austria's reform (Quinn, 2016).
} 
most districts have no interventions to address violence against women, even as its prevalence has increased substantially over time (Gender Monitoring Office, 2014, p. 3).

Two recent studies shed light on Rwanda's progress in implementing gender budgeting. One study concluded that Rwanda is making progress in integrating gender budgeting into the budget process, though there is scope for the government to improve the initiative at the sectoral level (Mukunda, 2011). The Ministry of Youth and Ministry of Health are specifically commended for the quality of their Gender Budget Statements.

Another study drew conclusions based on a randomized sample of stakeholders and relevant documentation (Mirwoba, 2013). Looking at the budgets and programs of the four pilot ministries in fiscal year 2010/2011, this study found that the Ministry of Agriculture spent almost one-third of its budget on gender-targeted outputs that year, the largest share of the four sectors, while the remaining ministries spent less than 15 percent each. The Ministry of Agriculture's large share reflected the priority attached to raising agricultural productivity and schooling of women, who account for the bulk of agricultural workers (Mirwoba, 2013). This focus is noteworthy in its wider applicability to other low-income agricultural-based sub-Saharan African countries, where women predominate in subsistence agriculture.

With regard to education, this study pointed to a number of programs to improve the supply of books and sanitation in schools, critical factors in encouraging girls' attendance in schools. In addition, there were programs to train teachers and parents to promote participation of girls in science and technology, where girls remain significantly underrepresented. In health, there were programs to increase trained health personnel, especially related to maternity services, and a program directed to female-headed households who confront challenges in accessing subsidized health care in Rwanda. Other programs focused on mitigation of malnutrition and malaria, especially among expectant women and their children.

Figure 6 presents some comparisons of Rwanda's progress in key indicators of women's development, including education, health, and labor force participation, and the same two overall indices of gender equality, the Gender Development Index and Gender Inequality Index. Like Uganda, we compare Rwanda's progress to that of a group of comparator countries. The figure suggests that Rwanda made improvements in educational enrollment at all levels over the period 1990 to 2012. It started the period with a higher rate of enrollment in primary and secondary levels and sustained a difference in the latest period. In tertiary enrollment, it nearly closed the gap with the comparator group. In decreasing maternal mortality, Rwanda made substantially more progress than comparators. Other indicators showed Rwanda doing well compared to comparators. It retained its superior performance in terms of women's labor force participation. It also built upon its above average gender equality index ratings by improving more than the comparators. 
Figure 6. Trends in Gender Inequality in Rwanda and a Comparator Country Group

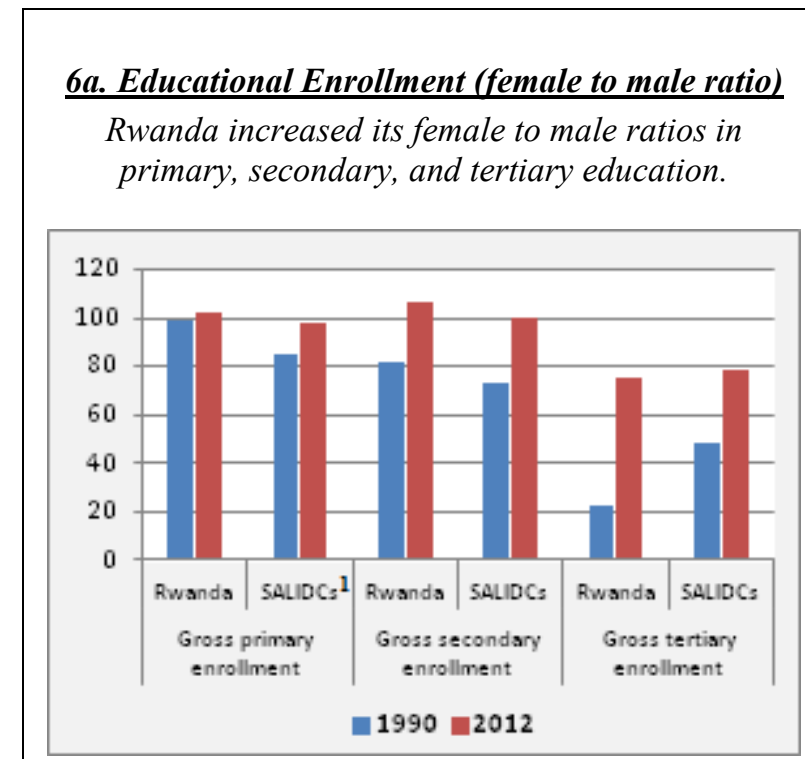

6c. Labor Force Participation (ages 15 - 64)

There was little change in the labor force participation rates in Rwanda, although the female to male ratio was above one in 2013.

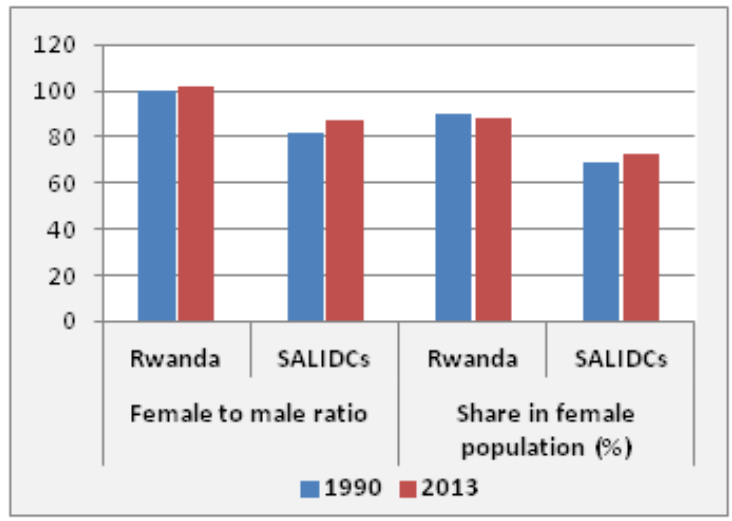

6b. Maternal Mortality Ratio (modeled estimate, per 100,000 live births)

Rwanda had almost double the maternal mortality ratio of its comparator group in 1990, but by 2013, had made more progress than these countries.

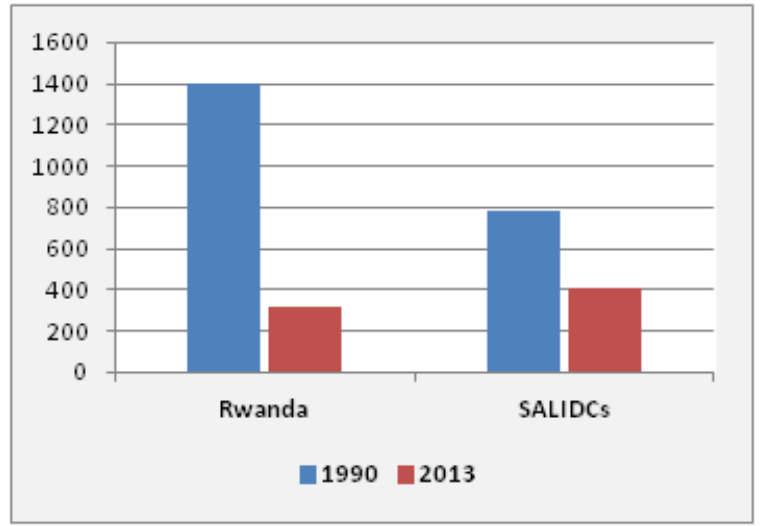

6d. Gender Inequality Indices

Rwanda performs better than its regional counterparts on two measures of overall inequality.

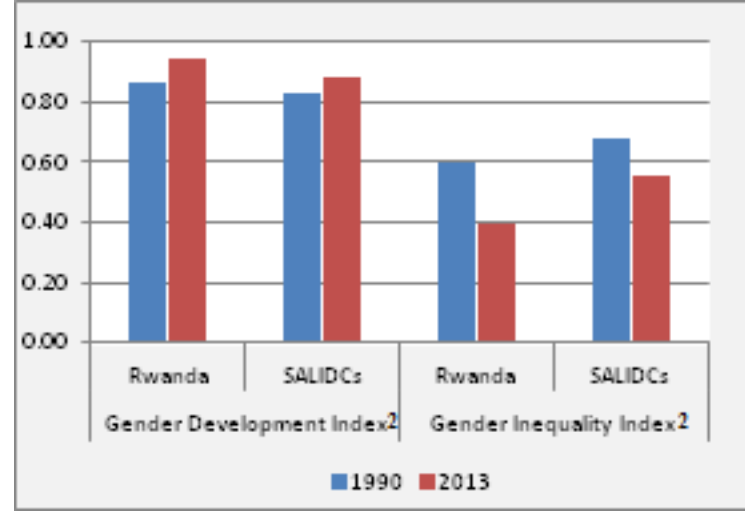

Sources: World Bank, World Development Indicators; Stotsky et al. (2016); IMF staff estimates.

${ }^{1 /}$ SALIDCs represents a group of low-income developing countries in Sub-Saharan Africa that we are using for comparison: Benin,

Cameroon, Comoros, Ethiopia, Gambia, Ghana, Kenya, Lesotho, Madagascar, Mozambique, Sao Tome Principe, Senegal, Tanzania, Togo,

Uganda, and Zambia.

${ }^{2}$ A higher Gender Development Index indicates greater gender equality, while a higher Gender Inequality Index implies greater inequality.

Figures 7 and 8 capture progress that could be attributable to gender budgeting by showing the situation in the period before and after gender budgeting's introduction (we use the second initiative to date the beginning because it led to a sustained effort). We see that females closed the gap with males in primary and secondary enrollment, with some evidence of a faster rate of closure in secondary enrollment, in the period following the introduction of gender budgeting. By period end, female enrollment was, in fact, higher than male enrollment. In decreasing the maternal mortality ratio, Rwanda made progress in both the period before and after the introduction of gender budgeting. 
Figure 7. Rwanda: Trends in School Enrollment (female to male ratio)

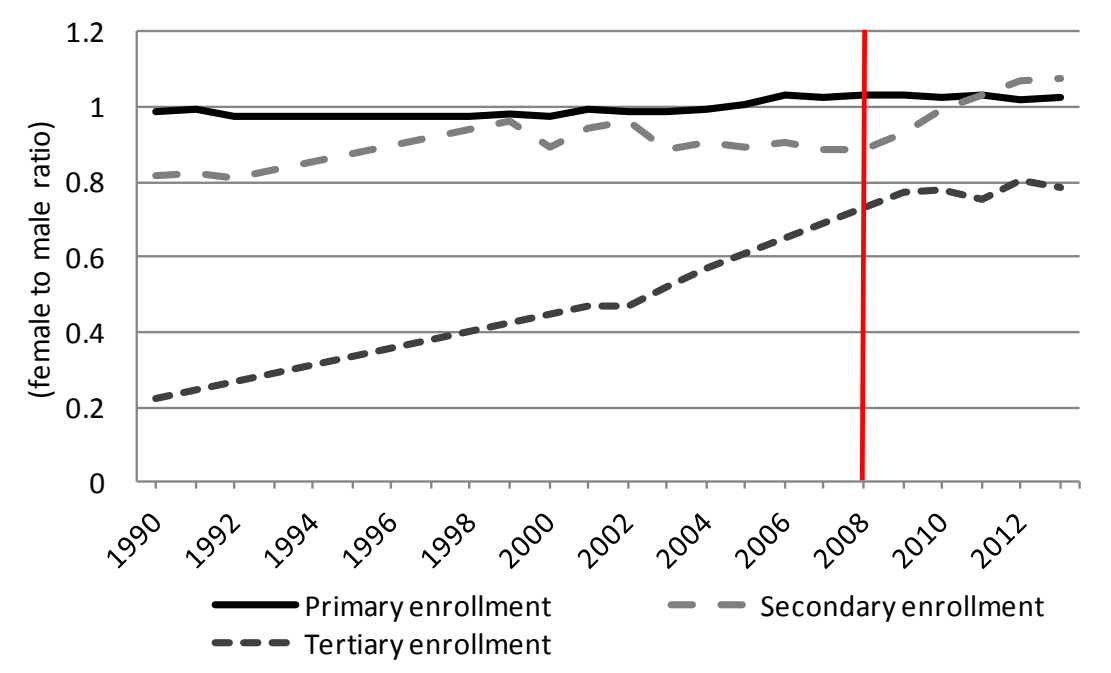

Sources: World Bank, World Development Indicators; IMF staff estimates.

Note: The vertical line indicates the start of the second gender budgeting initiative, this time led by the Ministry of Finance in 2008.

Figure 8. Rwanda: Trends in Maternal Mortality and Health Expenditure

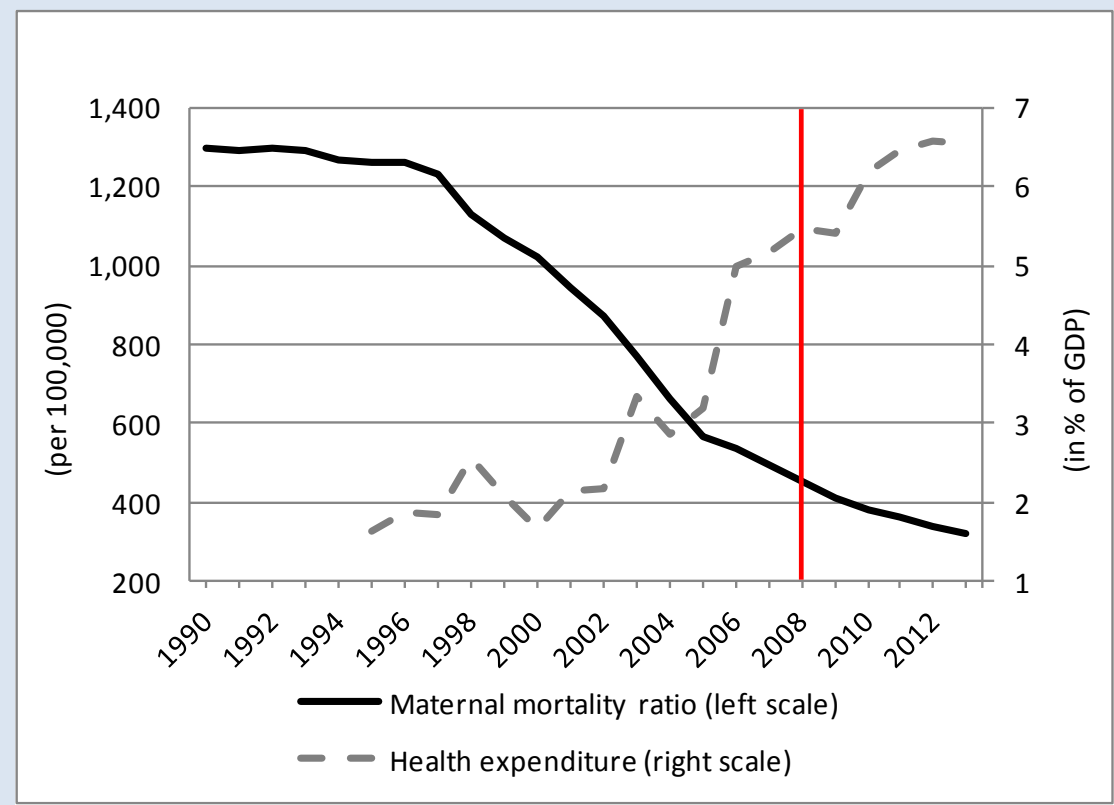

Sources: World Bank, World Development Indicators; IMF staff estimates.

Note: The vertical line indicates the start of the second gender budgeting initiative, this time led by the Ministry of Finance in 2008.

\section{Lessons from Rwanda}

Rwanda shows that it is possible to embed gender budgeting into the normal budgetary processes of a national government and subnational governments to address identified gender gaps and girls' and women's needs. In Rwanda, the government and the Ministry of Finance, specifically, tried to find a constructive approach to address gender-oriented goals through the government budget. The selection of pilots across sectors encompassing social, economic, 
and infrastructure issues was also notable, emphasizing the importance of addressing genderoriented issues comprehensively. The authorities' objective to match the format of gender budgeting to its program-budgeting approach likely contributed to success. Moreover, the discretion left to ministries and other government entities to identify critical issues is also a strength of gender budgeting in Rwanda in that it allowed civil servants to consider the most effective approach to addressing agreed goals. The Gender Monitoring Office was established to ensure that gender budgeting was put in place as intended and was serving its intended purposes. Such an accountability mechanism is often lacking in gender budgeting initiatives.

\section{Other Examples of Gender Budgeting in Sub-Saharan Africa}

\section{South Africa ${ }^{16}$}

South Africa has had two distinct gender budgeting efforts, both of which led to some fiscal policy and administrative changes. However, both initiatives waned, even though the government indicates that it remains firmly committed to gender equality and addressing women's needs.

South Africa is a middle-income country and the most industrialized country in sub-Saharan Africa (IMF, 2014a). The government's recent report to the Beijing +20 meeting lays out many of its commitments in the areas of gender equity and women's advancement (Department of Women, Children, and People with Disabilities, 2014). It acknowledges that although South Africa has made progress in addressing poverty and gender inequality, poverty and unemployment rates remain significantly higher for women than men.

Inspired by the Australian Women's Budget (the first gender budgeting initiative), a coalition of parliamentarians and nongovernmental organizations started the Women's Budget Initiative in South African in 1995. ${ }^{17}$ The initiative arose in the period following the end of apartheid with the adoption of a new Constitution (Budlender, 2002).

The Women's Budget was an annual publication that analyzed and provided policy prescriptions on issues of importance to women, to inform budgetary discussions. The document covered a range of issues over the years, including education, health care, welfare, housing, and jobs and public employment, and violence against women, and extending over time to cover revenue, donor, and intergovernmental finance issues. Support for the Women's Budget Initiative waned, reflecting in part the departure of a number of high level appointees in Parliament and the Ministry of Finance over time (Budlender, 2002).

A second initiative was piloted in 1998-1999 in the National Department of Finance (now National Treasury), with the technical support of some of the same people who had

\footnotetext{
${ }^{16}$ This discussion draws heavily upon the written submission of the South African Delegation to the International Conference of Gender Budgeting in Marrakech in November 2012, organized by the Ministry of Economy and Finance of Morocco.

${ }^{17}$ The two nongovernmental organizations were the Budget Information Office of the Institute for Democracy in Africa (IDASA) and Community Agency for Social Enquiry (CASE), with lead researcher, Debbie Budlender.
} 
introduced the Women's Budget. ${ }^{18}$ The South African effort was part of a broader Commonwealth Secretariat initiative that involved several Commonwealth countries. In the two years of the second South African initiative, the government discussed gender-oriented issues in its standard budget documents and included statistics on the role of gender in various sectors of the economy and the actions needed to achieve a greater female presence.

Even though the initiative waned, several departments of government undertook gender budgeting-related activities subsequently. The Department of Trade and Industry was one of the first departments to observe that the department allocated only a small fraction of its budget to small, medium and micro-enterprises, even though women are more likely to be owners of these types of enterprises. This observation resulted in increased allocations to the budget to promote more women's management and ownership. The Department of Social Development chose five budget programs and sub-programs to assess how staff understood gender-oriented issues and addressed them by budgeted activities.

Over time, several fiscal policy or program changes at the national level were attributed to gender budgeting or related initiatives: ${ }^{19}$

- The zero rating of paraffin (i.e., kerosene) in the VAT in 2001 to reduce the tax burden on poor women who rely on this source of fuel.

- The Child Support Grant to primary caregivers (Figure 9).

- The increase in the allocation by the Department of Trade and Industry for small, medium and micro enterprises, which is seen to benefit women-run businesses.

- The equalization of the amount spent on prison rations for male and female prisoners.

There were also a number of provincial initiatives. In 2003, the Premier's Office of Gauteng Province developed a policy on women's needs and incorporated relevant statements into the main budget statement. Budget officials were asked to identify outputs and outcomes - those targeting women and girls specifically and those that did not but benefited women and girls and promoted gender equality, and those benefiting women employees in Gauteng Provincial Government.

In recent years, the Ministry of Women, Children, and People with Disabilities partnered with the Motsepe Foundation, to restart gender budgeting at the national level. After conducting a review, it offered a set of recommendations for health; agriculture, forestry, and fisheries; energy; and trade and industry (Motsepe Foundation, 2013). For health, it recommended sustaining adequate spending on health, particularly for programs to reduce maternal mortality and improve infrastructure for delivery of health services.

\footnotetext{
${ }^{18}$ These were Debbie Budlender, Diane Elson, and Rhonda Sharp, who developed the analytical tools for gender budgeting. The Commonwealth Secretariat also developed a number of tools to promote the adoption of gender budgeting, such as the incorporation of gender-oriented considerations into medium-term budgetary planning, gender-aware policy appraisal and budget statements; gender-disaggregated beneficiary assessments and public expenditure and tax incidence analysis; and a gender-disaggregated analysis of the impact of the budget on time use. See Budlender and Hewitt (2002, 2003); and Budlender, Elson, Hewitt, and Mukhopadhyay (2002).

${ }^{19}$ As reported in the response questionnaire for the Marrakech High Level Gender Responsive Budgeting Conference of 2012.
} 
Figure 9. South Africa: Child Support Grant Coverage

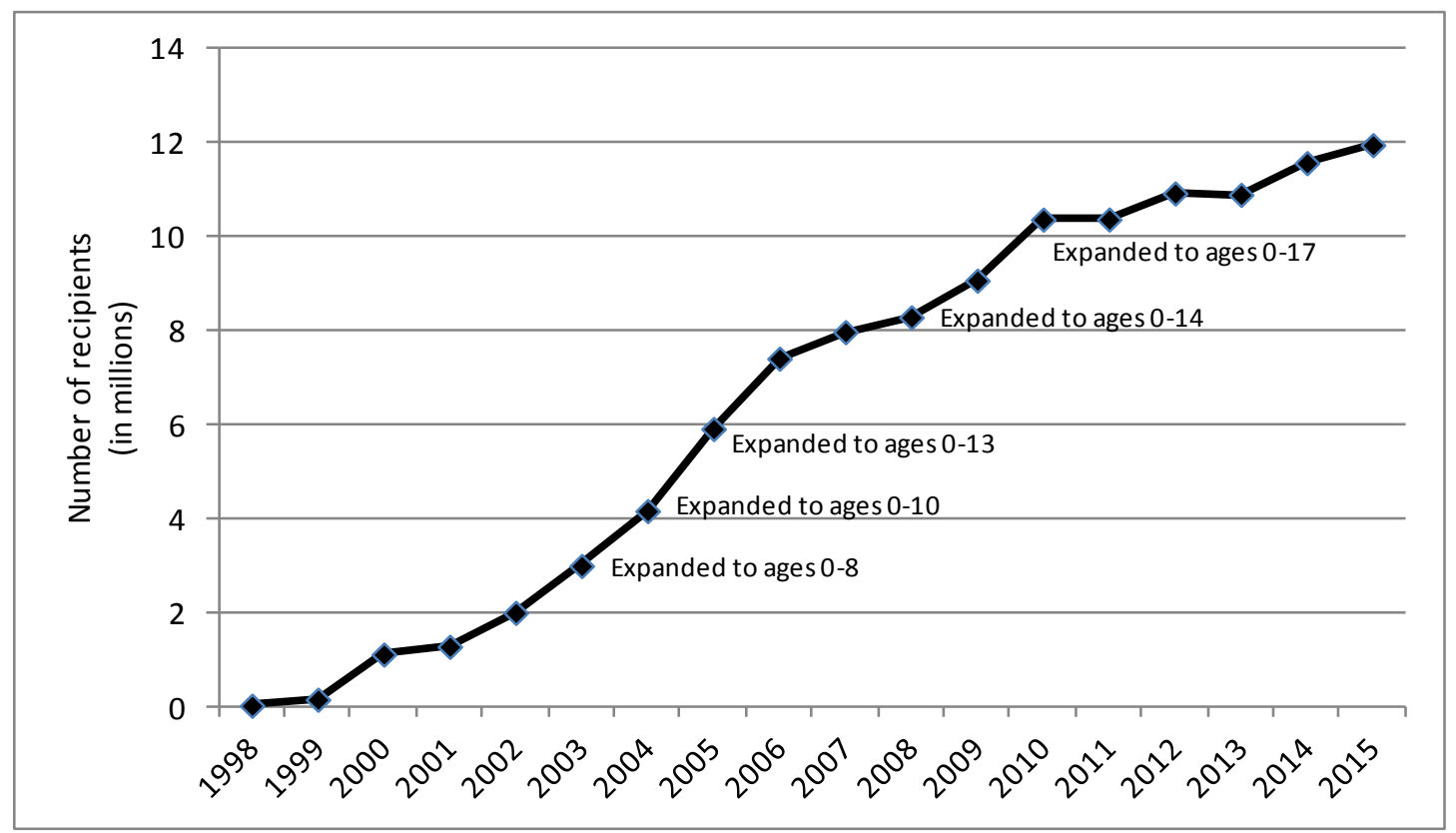

Sources: UNICEF, DSD and SASSA (2012); and SASSA (2013, 2014, 2015).

For agriculture, it pointed out the need for a policy that takes account of the importance of women both in subsistence agriculture and in paid agricultural work, in addition to a program to reduce hunger. For energy, it recommended taking full account of women's role in the household for lighting, heating, and cooking. For trade and industry, the report proposed the design of programs to support women's participation in the business sector and equitable representation of women in business activities.

The review emphasized the importance of building institutions and making use of sexdisaggregated data. Furthermore, it proposed that government provide gender units with adequate resources, technical skills, and knowledge to translate concepts into practice; train economists in applying gender analysis; and improve monitoring mechanisms for tracking budget outcomes in terms of reducing gender gaps.

It is worth emphasizing that these recommendations, though set within a South African context, could equally well apply to the range of sub-Saharan African countries in which women have a similar role in the household and economy.

Although separate from the gender budgeting initiatives, South Africa has also reformed its tax system to be more fair to women. In the apartheid period, the tax system contained several elements of explicit discrimination against women (Budlender, Casale, and Valodia, 2010). One important difference was that the tax schedules defined a "married person" as male with a separate category provided for "married women." Married men were taxed at a lower rate than unmarried persons, and unmarried persons were taxed at lower rate than 
married women. The distinction between married men and women was justified on the grounds that married women were secondary earners in the household. In addition, allowances for dependents accrued only to married men, among several other discriminatory measures. In the context of reform of the income tax, in line with the new Constitution, in 1995, South Africa moved to unify the rate schedule and eliminate other forms of explicit discrimination against women in the tax code. Nonetheless, concern remains that the income tax code contains elements of implicit bias against single-adult headed households, which is very common among women in South Africa. ${ }^{20}$

Budlender et al. (2010) also assess differential tax burdens in South Africa for indirect taxes (principally value added taxes, excises, and the fuel levy) by household type (defined in the study). They find that there is no implicit bias overall against "female-type" households because high taxes on alcohol, tobacco, and fuel raise the relative burden on households headed by men, who consume more of these goods, and the zero-rating of basic food and paraffin has a disproportionate benefit in reducing the tax burden of households headed by women.

South Africa has many of the prerequisites for putting in place effective gender budgeting. It has relatively well functioning budget institutions and a legal framework for addressing gender equality and women's needs. The zero rating of paraffin and the child support grant are important achievements attributable to gender budgeting. Although South Africa's gender budgeting initiatives may have waned, the government indicates it remains firmly committed to women's equality. South Africa's gender budgeting initiatives did play an important role in inspiring other initiatives in the region and elsewhere.

\section{Tanzania}

Tanzania is a low-income, agricultural-based developing country, which, like Uganda and Rwanda, has made significant progress in improving macroeconomic control and strengthening growth (IMF, 2014c). As in these other countries, women need more education, better health care, and better work opportunities. Tanzania's gender budgeting efforts were stimulated by a coalition of nongovernmental organizations that produced considerable research for integrating women's needs in fiscal policies and employing time use data to assess the effect of unpaid labor on women's lives. Their efforts suffered because the government did not fully incorporate an approach to gender equality in the budget. Moreover, the government relied on donor funding rather than its own revenue sources to sustain funding for gender-oriented goals.

Tanzania was a pioneer in gender budgeting in Africa in 1997 (Rusimbi, 2002; Mhina, 2007). Its first efforts began as a civil society initiative involving a network of nongovernmental organizations such as the Tanzania Gender Networking Program and Feminist Activism. The aim of this coalition was to address gender equality and women's needs through the budget, especially in the social sectors (Rusimbi 2002). Research to inform policy making was a central part of their efforts. One of the coalition's first products was a book, Budgeting with a

\footnotetext{
${ }^{20}$ Budlender et al. (2010, p. 212).
} 
Gender Focus, outlining the concepts of gender budgeting. A tangible outcome was that, in 2000, the government undertook a pilot project with six ministries - health, education and culture, agriculture and food security, water, regional administration and local governments, community development, gender and children's development, to integrate concerns into the budget process.

Its later efforts began in 2001, with the coalition of nongovernmental organizations continuing its focus on incorporating gender-oriented concerns into the budget process but elevating gender-oriented concerns to macroeconomic programming (Rusimbi, 2002).

There were some achievements in girls' education: the establishment of a program for girls' secondary education to increase low-income girls' access to secondary education; scholarships for female students at the university level; a program to encourage more girls in science and math-based disciplines; and other measures to increase female enrollment and retention rates in higher levels of education (Mhina, 2007, p. 12).

Despite these efforts, the impact of gender budgeting was limited, as suggested by two reviews. A World Bank Strategic County Gender Assessment in 2004 advocated incorporating more gender-oriented objectives into government poverty-reduction programs (Blackden and Rwebangira, 2004). The Bank saw the efforts to mainstream gender issues in the budget as consistent with the government's move to an output/outcome-oriented budget and recommended providing more guidance to budget officers in addressing gender-oriented issues (Blackden and Rwebangira, 2004, p. 25). Similarly, a review by UNIFEM, in 2008, largely concurred (Kytola, 2008). It noted that awareness of budgeting was widespread but its implementation was inconsistent (Kytola, 2008, p. 10).

A Gender Mainstreaming Working Group-Macro Policy was established to provide a forum for dialogue between the government and other stakeholders on gender-oriented economic policy matters, and was housed in the Ministry of Community Development, Gender and Children. It commissioned the Tanzania Gender Networking Program to study issues relevant to guiding fiscal policies, such as how to address the problems of a large number of femaleheaded households and the burden of home-based care in HIV/AIDS (Kytola, 2008, p. 34). The Tanzania Gender Networking Program also encouraged the government to conduct the first Tanzania study on individuals' use of time and suggested disaggregating labor into men and women in macroeconomic models, to capture the different roles of women (Rusimbi and Kikwa, 2008). It has also run courses though its Gender Training Institute.

The Ministry of Finance ${ }^{21}$ and the government's Beijing + 20 report (MCDGC and MESWYWCD, 2014, pp. 12-14) provided an updated view on the status of gender budgeting in the Tanzanian government. First, the government has established a core gender budgeting team within the Ministry of Finance to oversee the implementation of gender budgeting in all sectors of the government and in local governments, working in collaboration with other groups. Second, the national government supports the integration of gender equality

${ }^{21}$ Tanzania government response to IMF questionnaire, unpublished, 2015. 
commitments in government programs and policies and tracking gender-oriented spending at the national and local levels.

Since 2010, the Ministry of Finance has given gender-specific instructions to national and local government agencies in developing their budgets. It has earmarked two ministries, the Ministry of Agriculture and the Ministry of Labor, and two local government authorities, Temeke Municipality and Morogoro District Council, to pilot a new phase of the implementation of gender budgeting.

Some of the projects influenced by the current gender budgeting efforts include:

- Education: building hostels for girls' secondary schools and encouraging girls to pursue science as a field of study in college.

- Agriculture: providing subsidies for poor families, many of which are female-headed. These subsidies cover farm inputs, such as fertilizer, seeds, and pesticides.

- Water: building water wells for 10 villages under each local government's authority to reduce the distance to fetch water.

- Tax exemptions: implementing a tax exemption on import duties for material used for production of women's sanitary towels.

In 2013, the women's caucus in parliament, the parliamentary budget committee, and other groups planned for the implementation of gender budget statements. Permanent ministerial secretaries attended orientation sessions and staff for gender-oriented issues, from ten regions and the district councils, were trained in gender planning and budgeting. The semiautonomous region of Zanzibar has made less progress in adopting any kind of gender budgeting (MCDGC and MESWYWCD, 2014, pp. 14).

Tanzania's experience with gender budgeting is mixed. The longstanding pressure of nongovernmental organizations has been instrumental in keeping efforts to address gender inequality and women's needs alive. Their push for time use data and the elevation of genderoriented concerns to macroeconomic modeling are notable. However, gender budgeting has not been fully embedded in the government budget. Tanzania's renewed interest in gender budgeting holds promise for it to better incorporate gender-oriented goals into budget policies and programs.

\section{Benin $^{22}$}

Benin began its gender budgeting initiative in 2013, with the requirement that that Budgetary and Economic Policy Note and budget circular take account of gender-oriented issues and women's needs. Benin's efforts are monitored and led by a technical team within the Ministry of Economy, Finance, and Denationalization Programs. Benin receives technical and financial support from the German Technical Cooperation Agency and the United Nations Development Program. A Directorate for the Promotion of Women and Gender was installed in the Ministry in Charge of Families. Offices in sectoral ministries receive budget

\footnotetext{
${ }^{22}$ Benin government response to the IMF questionnaire, unpublished, 2015.
} 
appropriations for activities related to the fulfillment of gender-oriented objectives.

Parliament and nongovernmental organizations are being engaged to help with development of the initiative.

Beginning with three ministries in 2013, gender budgeting efforts were expanded to five ministries in 2014, and then further expanded to ten ministries, in 2015, including key ministries in agriculture, energy, water, industry, infrastructure, health, and education. Currently, the initiative is expenditure-oriented. However, the government is exploring strategies for including a revenue dimension. The General Directorate of Budget is also developing plans for hiring more women, revising government procurement policies as regards contracting with women, and incorporating the use of sex-disaggregated statistics.

\section{Cameroon $^{23}$}

Cameroon began its gender budgeting initiative in 2009 as a partnership between its Ministry of Finance and UN Women. It is led by a team from the Ministry of Finance, the Ministry of Economy, Planning and Territorial Development, and the Ministry of the Advancement of Women and the Family. The initiative includes all sectors, although some sectors have been identified as having priority: education, health, and agriculture. Monitoring of the initiative takes places at two levels. Each governmental institution has a task force responsible for monitoring implementation at the ministerial level, while at the national level, a steering committee issues general guidelines for implementation.

\section{Ethiopia $^{24}$}

In 1993, the Ethiopian government introduced a National Policy on Women to address gender inequality and women's needs. In 1995, constitutional mandates for gender equality and women's rights followed. ${ }^{25}$ The first efforts at gender budgeting came in 2008 when the Gender Department at the Ministry of Finance and Economic Development and the Ministry of Education, in partnership with UNICEF Ethiopia and the British Council, developed a manual on implementing gender budgeting to increase female school enrollment. The Prime Minister's Office and Ministries of Education and Women's Affairs, Parliament, local governments, and schools were all given guidelines and checklists to use for planning and budgeting for girls' education. For example, the Prime Minister's Office was assigned the

\footnotetext{
${ }^{23}$ Cameroon government response to the IMF questionnaire, unpublished, 2015.

${ }^{24}$ This section draws extensively from the Ethiopia government response to the IMF questionnaire, unpublished, 2015.

${ }^{25}$ In addition to establishing equal rights for men and women, the Ethiopian constitution states that "[c]onsidering that women have traditionally been viewed with inferiority and are discriminated against, they have the right to the benefit of affirmative actions undertaken for the purpose of introducing corrective changes to such heritage. The aim of such measures is to ensure that special attention is given to enabling women to participate and compete equally with men in the political, economic and social fields both within public and private organisations." Furthermore, oppressive "stereotyped ideas and customs" that negatively impact women were prohibited. Other notable features include provisions for maternity leave, and equal marriage and property rights. Proclamations in 2003 and 2007 prohibited gender-based discrimination in employment and wages, while the Civil Servants Proclamation 515/2007 provided for affirmative action for female civil service candidates (Authorities' questionnaire response, 2015).
} 
responsibilities of checking that the budget call circular mentioned gender budgeting, ensuring an allocation of funds for gender-oriented purposes, and promoting the project to Parliament (MOFED and MOE, 2009). Local and school authorities were instructed to focus on barriers to female enrollment and retention and determine budgetary needs for female and male pupils. This program has succeeded in significantly reducing the female dropout rate, according to the authorities. UN Women (2014) also pointed out that the Ministry of Finance and Economic Development has led gender budgeting training for all federal ministries, and the ministries included gender goals and activities as part of their annual budget requests. Beginning in the 2011/2012 fiscal year, Ethiopia began allocating a share of its federal budget to achieving the Millennium Development Goal targets, many of which address women's needs. The 2014/2015 fiscal year budget dedicated approximately eight percent of the total budget to these activities and programs (MOFED website). ${ }^{26}$

Courses at the Ethiopian Civil Service University are another important highlight of the gender budgeting effort. ${ }^{27}$ The university, which is funded primarily by the federal government, offers a two-day training course on gender budgeting, as well as other courses on analysis, audit, mainstreaming, project planning, and monitoring and evaluation.

The gender budgeting effort in Ethiopia has also benefited from the involvement of nongovernmental organizations. One such example is the program between the Poverty Action Network of Ethiopia (with help from UN Women) and an administrative unit in the north of the country. ${ }^{28}$ The nongovernmental organization trained 30 members of the community on gender budgeting so that they could read and analyze local government budget documents and advocate for improved water facilities and access.

\section{The Gambia ${ }^{29}$}

Equal access to health care and education is an ongoing concern in The Gambia. The government has implemented gender budgeting programs in four ministries/sectors - The Office of the Vice President and Minister for Women Affairs along with the Ministries of Education, Health and Social Welfare, and Agriculture. The Ministry of Education is working to increase primary, secondary, and tertiary enrollment rates of girls. For example, the Gender Unit at the Ministry of Education provides a re-entry program for girls who would like to come back to school after dropping out due to personal circumstances. Also the Trust Fund for Girls provides funding from the government and charitable organizations to support educational attainment for girls at the basic level. Similarly, the Trust Fund for Boys disburses funds to boys, mainly in rural areas. Forty-two percent of the fiscal year 2015 budget for the Ministry of Health and Social Affairs was dedicated to the Reproductive and

\footnotetext{
${ }^{26}$ MOFED website, accessed on April 12,, 2016.

${ }^{27}$ The Ethiopian Civil Service University website, accessed on April 12, 2016. http://www.ecsu.edu.et/content/cross-cutting-issues

${ }^{28}$ UN Women website accessed, on April 12, 2016. http://www.unwomen.org/en/news/stories/2013/8/in-ethiopia-rural-women-improve-their-lives-befriendingbudgets

${ }^{29}$ This section draws extensively from The Gambia government response to the IMF Questionnaire, unpublished, 2015.
} 
Family Health Program, which offers free maternal health services, free health services for children under the age of five, and cash transfers to the needy.

\section{Mali $^{30}$}

Mali's gender budgeting initiative is a strategic pillar of its National Gender Policy, adopted in November 2010. Its objective has been to include in its budget preparation, planning and management a gender dimension to the allocation of public resources. Two ministries are responsible for the implementation of the initiative: the Ministry of Economy and Finance along with the Ministry for the Advancement of Women, Children, and the Family.

The initiative is designed to span 10 years. In its first phase, it targeted 10 priority sectors identified as having the potential to reduce gender inequality: Justice, Rural Development, Health, Education, Employment and Vocational Training, Water and Energy, Decentralization, State Reform, Budget Reform, and Communication.

Budget Call Circulars give clear instructions to these sectors to engage in gender-responsive planning and budgeting. Specifically, each department is asked to analyze the National Gender Policy action plan and make their own plans to reduce gender gaps; to generate gender-sensitive indicators; to allocate resources to these actions; ${ }^{31}$ and to produce a report to be consolidated in an Annex of the Finance Law. This report would form the basis for legislation by Parliament (in approving the annual finance bill) and oversight (in scrutinizing past performance in the light of current budget proposals).

The Ministry for the Advancement of Women, Children, and the Family along with the Ministry of Economy and Finance are tasked with monitoring implementation of the initiatives through annual performance reports, the gender report, and a bulletin of statistics on men and women. Since 2011, a budget annex on gender has been drafted and attached to the finance law. The gender-oriented budget annex tracks performance on programs, objectives, and indicators in ministries involved in the implementation of the National Gender Policy action plan. Nongovernmental organizations participate in the initiative.

\section{Mauritius}

Gender budgeting in Mauritius dates back to 2001 when the Ministry of Women's Rights, Child Development, and Family Welfare (MWRCDFW), in collaboration with UNDP, hosted a two-day national consultative workshop on "Engendering the Budget" (SADC, 2014). The workshop resulted in the development of an outline for a three-year Action Plan on gender budgeting and the establishment of a national level committee, consisting of representatives from the Prime Minister's Office, Ministry of Finance, Ministry of Women's Rights, Child Development and Family Welfare, UNDP, and others (Verdickt, 2009).

\footnotetext{
${ }^{30}$ This section largely draws from the Mali government response to the IMF questionnaire, unpublished, 2015.

${ }^{31}$ This instrument was directly inspired by the Moroccan Gender Reports (see Kolovich and Shibuya, 2016) but improved upon it by specifying that allocations had to be made for these priority actions in the program budget.
} 
In 2007, Ministry of Women's Rights, Child Development, and Family Welfare entered into a strategic partnership with the Ministry of Finance and Economic Empowerment in a push to align the national gender policy with current governmental fiscal reforms (i.e. the move towards Program-Based Budgeting and Performance Management Systems). This partnership resulted in the Ministry of Finance and Economic Empowerment including gender in its 2008/2009 budget circular. To complement this, a training manual was produced to provide guidelines on how to effectively mainstream gender perspectives into Program-Based Budgeting in sectoral ministries (Verdickt, 2009). Since 2009, the Ministry of Women's Rights, Child Development, and Family Welfare has facilitated the development of sectoral gender policies with various ministries, and by 2012, twelve ministries had sectoral gender policies in place (SADC, 2014).

\section{Mozambique}

The Ministry of Planning and Finance piloted Mozambique's first gender budgeting effort in 1998, when ministries were instructed to provide a breakdown by sex of expenditures on human resources and investment. As Ibraimo (2003) pointed out, this breakdown shed light on gender inequalities in labor allocation; for example, female employees were often employed in technical or auxiliary roles despite having the same qualifications as men who were employed in more senior positions. However, this early initiative was short-lived and gender budgeting in Mozambique did not gain much traction until UNIFEM launched a new attempt in 2003.

The first part of the UNIFEM effort lasted two years from 2003-2004 and centered around raising awareness and building capacity, while the second phase ran from 2005-2008 and sought to include gender-oriented concerns in policy and budget processes, focusing on key areas such as HIV/AIDS, violence against women, and maternal health. ${ }^{32}$ The Mozambican government noted that the Gender Policy and Implementation Strategy was also approved in 2005 with the goal of promoting gender equality and increasing women's participation in development opportunities. Notably, the Strategy included measurable targets on sexdisaggregated data collection; female admission, retention, and graduation rates from school; female employment in nonagricultural work; and reduced maternal mortality rates and increased assisted birth care. ${ }^{33}$ Also established in 2005, the Women's Parliamentary Office was tasked with increasing female representation in leadership roles.

Progress on incorporating gender-oriented concerns into the budget process came in 2007, when the Economic and Social Plan instructed ministries to not only outline their goals but also identify potential consequences in terms of gender equality for these goals (Holvoet and

${ }^{32}$ UN Women website accessed on April 11, 2016. http://www.gender-

budgets.org/index.php?option $=$ com_content\&view $=$ article\&id $=747 \&$ Itemid $=767$.

${ }^{33}$ Specific targets mentioned in the country authority's response include increasing, by 2015:

- admission, retention, and graduation rates of girls in educational institutions to 50 percent;

- the percentage of women employed in the non-agricultural sector to 50 percent;

- the percentage of women in governing and decision making bodies to 40 percent;

- assisted births to 60 percent of total births; and

- the gross female enrollment rate in primary education from 71 percent to 90 percent. 
Inberg, 2014). Since 2009, budget call circulars have included criteria about women. However, a 2014 report by the Southern African Development Community mentions that while Mozambique, along with Mauritius, Zambia, and Zimbabwe, includes gender in its budget call circulars, many line Ministries in the four countries encounter challenges in practically applying them.

A salient feature of Mozambique's efforts has been its collaboration with nongovernmental organizations such as Forum Mulher and the Tanzanian Gender Networking Program. These two organizations provide technical assistance, training, and logistical support to ministry staff (SADC, 2014). An additional benefit of this close coordination with nongovernmental organizations is that out of the 15 Southern African Development Community members, "Mozambique was the only country that displayed serious efforts to learn from the gender budgeting model of another SADC country [Tanzania]" (SADC, 2014).

Finally, another notable component of Mozambique's gender budgeting effort is its attention to climate change. More than 60 percent of its population lives in low-lying coastal areas; moreover, its economy depends heavily on agriculture, particularly fishing. With the assistance of UN Women, the International Union for the Conservation of Nature Global Gender Office, and the Danish International Development Agency, Mozambique developed an Environment and Climate Change Strategy and Action Plan, with special attention to women's needs.

\section{Nigeria}

The Nigerian federal government, in partnership with the United Kingdom's Department for International Development, introduced a gender budgeting initiative called "Growing Girls and Women in Nigeria" (G-WIN) in 2012. Five ministries, Agriculture, Public Works, Health, Water Resources, and Communication and Technology, were selected for this initiative. During the inaugural meeting of the Gender Equality Community of Practice for Finance Ministers ${ }^{34}$ in 2014, the Nigerian Minister of Finance reported on the project's early successes.

The Ministry of Health pinpointed the issue of treating women with fistulas, a debilitating post-birth condition that can lead to shame, divorce, and family rejection. According to the United States Agency for International Development, Nigeria has the highest number of women who suffer from fistulas, with about half of all cases world-wide, and anywhere from 50,000-100,000 new cases each year. ${ }^{35}$ Under the G-WIN project, the Ministry of Health allocated resources to recruit and/or train additional doctors to perform the surgery necessary

\footnotetext{
${ }^{34}$ Then Nigerian Finance Minister Ngozi Okonjo-Iweala pitched the idea of creating a Gender Equality Community of Practice (COP) during the World Bank/IMF Annual Meetings in the fall of 2013. Shortly thereafter, in April, 2014, the inaugural meeting of the COP group took place with eight finance ministers, the president of the World Bank, and the executive director of UN Women in attendance. The group now has 16 countries on board and meets each spring and fall during the IMF/WB meetings.

${ }^{35}$ See USAID website: https://www.usaid.gov/results-data/success-stories/repairing-obstetric-fistula-nigeria.
} 
for correcting fistulas. It is estimated that more than 3,000 women were treated, but an extensive backlog of cases remains.

Nigerian female farmers account for 70 percent of all agricultural work, but have less access to agricultural inputs, contributing to female agriculture output being 40 percent lower than their male counterparts' output. The Ministry of Agriculture is trying to train more than 30,000 women on different or better farming methods. One crucial roadblock for female farmers has been access to finance because this hampered women's ability to procure seeds and fertilizers. Under the G-WIN initiative, two million female farmers received cell phones to improve access to and the exchange of information. The cell phones enabled women to use an e-wallet system to facilitate mobile money purchases of agricultural inputs.

Additional highlights of the G-WIN program can be found in reports of the Ministry of Public Works and the Ministry of Water. The Ministry of Public Works trained 1,500 women in road maintenance, which was previously viewed as a male-only occupation. The Ministry of Water constructed 120 water kiosks that were to be managed by women.

\section{Senegal}

Gender budgeting was initiated in Senegal under a UNIFEM program, with the first phase running from 2003-2005. The program set priorities on gender equality and poverty reduction (UNIFEM, 2009). The next phase, from 2005-2006, offered training workshops for ministries, local government, and civil society organizations. Beginning in 2007, UNIFEM coordinated with the National Budget Directorate and pushed for incorporating genderoriented issues in the budget call circular. Furthermore UNIFEM altered the players in the gender budgeting initiative by focusing less on civil society organizations and engaging more with parliamentarians. These efforts led to gender-oriented issues being included in the 2008 and 2009 budget call circulars and in the Poverty Reduction Strategy Paper. In addition, the Ministry of Agriculture was also able to create a gender-sensitive budget and a report on women's needs. One area for improvement, as observed in the UNIFEM evaluation, is the collection of sex-disaggregated data, which would improve the government's ability to develop gender-sensitive outcome indicators.

During the second phase of the program, the government conducted a review of the Poverty Reduction Strategy Paper and formulated the National Strategy for Gender Equality and Equity, which replaced the National Plan of Action for Women.

The National Strategy for Equality and Gender Equity comments on how sustainable development and poverty reduction cannot be achieved without addressing gender inequality. It further observes that despite gains for women in education, health, and economic opportunities over the last 20 years:

"women overwhelmingly continue to suffer disproportionately the burden of poverty and illiteracy; they still face serious violations of their human rights and their rights to sexuality and reproduction; they are the first victims of the HIV/AIDS; many are still at risk today of dying in childbirth. It thus appears that, despite the real progress made, much remains to be done to achieving 
equal rights and opportunities for girls and boys, men and women. This justifies the adoption of the gender approach as an analysis and planning tool in the formulation of this strategy."

To reduce gender gaps, the Strategy calls for implementing gender budgeting throughout different levels of government, improving the national gender machinery, and allocating at least 15 percent of each sector's budget to address gender equity concerns. The Strategy appealed to local communities to take up gender budgeting, and to sustain their efforts, the Strategy noted that local, departmental, and regional governments should allocate 15 percent of their budget to women's advancement.

As of 2015, there is renewed interest in gender budgeting. ${ }^{36}$ For example, the "Support Program for Gender Sensitive Budgeting" was included in the 2015 national budget. This program finances training and "mapping gender inequalities in the fiscal sphere." The threeyear Program on Public Investment for 2015-2017 provides budget information on allocations for gender equality programs.

\section{Zimbabwe}

Zimbabwe's experience with gender budgeting dates back to 1999, when a civil society organization, the Zimbabwe Women's Resource Centre and Network, tried to stimulate a gender budgeting initiative in government through a "Gender, Economic Policies and Public Finance Programme," which was intended to mainstream gender into government macroeconomic frameworks, policies, programs, and budgets (Ngwenya, 2013).

The government officially adopted gender budgeting in 2007 with the goal of using its National Gender Policy to influence the budget. The program is managed by the Ministry of Women Affairs, Gender and Community Development in collaboration with the Ministry of Finance and with technical assistance from the Zimbabwe Women's Resource Centre and Network. The program created focal points in all line ministries. These focal points act as liaison between the gender machinery and their respective ministries. These focal points are responsible for submitting quarterly reports to the Ministry of Women Affairs, Gender and Community Development. The initiative also included a training component where directors of finance, budget officers, and focal persons were all trained and sensitized in gender budgeting (SADC, 2014).

The 2007 budget call circular instructed ministries to implement gender budgeting in their budget preparation and planning. In 2008, the budget call circular expanded gender budgeting to the subnational level and in 2011, the ministries were also instructed to prepare their budgets in line with gender budgeting goals and with taking into consideration the UN's Millennium Development Goals. To assist officials in the adoption of gender budgeting, the government produced two guides a "Gender Budgeting Training Manual and Tool" and "Guide for Technocrats" (SADC, 2014).

The implementation of gender budgeting has been hampered by Zimbabwe's macroeconomic

\footnotetext{
${ }^{36}$ Senegal government response to the IMF questionnaire, unpublished, 2015.
} 
dislocations and budget problems in the past decade. Rural women and girls have been especially hard hit by the scaling back of many public services, including electricity supply (Manyeruke and Hamausw, 2013). In 2012 only 6 out of the 38 vote appropriations in the national budget included a line item under "Programmes for gender mainstreaming" (SADC, 2014).

\section{Conclusions and Lessons for Improving Gender Budgeting in the Region}

Many countries in sub-Saharan Africa have adopted some form of gender budgeting over a period of almost two decades. The two most successful initiatives are in Uganda and Rwanda, because gender budgeting became integral to the budgetary process and influenced fiscal policies, even though in practice, there remains considerable scope for improving the substance of gender budgeting in both countries. South Africa and Tanzania's gender budgeting initiatives, plus specific aspects of the efforts in other countries in the region, provide lessons from which future initiatives can learn.

We note several identifiable achievements. South Africa adopted a number of fiscal policies designed to assist poor women, specifically, and their families. Similarly, in Rwanda, the government's broad-based efforts to incorporate gender equity into sectoral policies and programs appear to have sped up progress on education and health-related goals. The coherent manner in which Rwanda implemented gender budgeting into its program-budgeting framework is also notable. Uganda, too, has demonstrated a sustained commitment to addressing gender equity and the advancement of women through the budget, with evident success in adapting education and health programs to address women's needs.

The use of fiscal policies and administration to address gender-oriented goals clearly required strong leadership from Ministries of Finance, as is seen in Rwanda and Uganda.

Nongovernmental organizations played an essential part in keeping gender equality and women's needs in the forefront of budget discussions. In several countries, nongovernmental organizations were instrumental in getting the initiatives going. Parliaments also played a role in catalyzing gender budgeting initiatives.

It seems that gender budgeting is more likely to be successfully integrated into ministerial, sectoral, and local government policies and programs when government institutions were given directives to respond to government priorities with regard to gender equality and women's needs, as in any number of the countries, including Rwanda, Uganda, South Africa, Tanzania, Nigeria, and Ethiopia. While adequate funding for public services remains a challenge throughout sub-Saharan Africa, gender budgeting is a vehicle for ensuring that gender-oriented goals receive adequate consideration in competing for scarce funds and motivating better program design.

Gender budgeting has appeared to be successful only in limited circumstances, and where there was sustained effort on the part of governments to implement it. Institutionalization in government laws is critical. The role of the Ministry of Finance to mandate that sectoral ministries and local governments incorporate gender-oriented goals into their plans is also critical. Monitoring and evaluation of outcomes is essential to ensure that ministries and 
agencies of the government set appropriate goals, allocate funds to achieve them, and think about the most effective approach to achieving the goals.

There is considerable scope for strengthening the analytical basis for setting and meeting gender-oriented goals, and for gaining an understanding of the gains of gender equality and a fuller role for women in economic markets. Research undertaken over the years, some evaluative, such as in Rwanda, and some analytical or prescriptive, as in South Africa and Tanzania, have clearly created a more fruitful environment for good policy making. Nongovernmental organizations and others have also contributed to a better understanding of the gains from gender equality and women's advancement. One particular emphasis should be how to address the needs of poor women in sub-Saharan African countries, for whom gender inequality and underdevelopment are more pervasive features of life, than for better off households.

Gender budgeting has stimulated much interest in unpaid care work, and time use studies providing data on how women and men spend their time are now more frequently available in the region. These data can be used to enlarge analytical frameworks to incorporate separate roles for women and men in the economy to capture the benefits of equalizing opportunities and capabilities of women and men. Time use data offer a largely unused opportunity to assess how the expansion of key public services, such as water and energy or electrical infrastructure, whose beneficiaries are not easily broken down by sex because the benefits flow to households or communities, can contribute to reducing the unpaid labor of women and girls, which inhibits their participation in the work force and in school.

The efforts in making budgets more attuned to promoting gender equality and women's advancement will be useful for achieving the UN's Sustainable Development Goals. National policy frameworks, including macroeconomic and fiscal policy, and public financial management reforms, can be framed with gender equity goals in mind. In this regard, strengthening domestic resources remains a priority to fund important public services. 


\section{References}

African Union, 2003, Protocol to the African Charter on Human and People's Rights on the Rights of Women in Africa (the Maputo Protocol), (Addis Ababa: African Union).

Andrews, Matthew, 2010, "How Far Have Public Financial Management Reforms Come in Africa?” HKS Faculty Research Working Paper Series, RWP10-018, John F. Kennedy School of Government, Harvard University.

Bandiera, Oriana and Ashwini Natraj, 2013, "Does Gender Inequality Hinder Development and Economic Growth? Evidence and Policy Implications," The World Bank Research Observer, Vol. 28, pp. 2-21.

Berg, Andrew, Norbert Funke, Alejandro Hajdenberg, Victor Lledo, Rolando Ossowski, Martin Schindler, Antonio Spilimbergo, Shamsuddin Tareq, and Irene Yackovlev, 2009, "Fiscal Policy in Sub-Saharan Africa in Response to the Impact of the Global Crisis," International Monetary Fund Staff Position Note 09/10 (Washington, DC: IMF).

Berik, Gunseli, Yana van der Meulen Rodgers, and Stephanie Seguino, 2009, "Feminist Economics of Inequality, Development, and Growth," Feminist Economics, Vol. 15, pp. 1-33.

Blackden, C. Mark, and Magdalena Rwebangira, and with support from Zahia Lolila Ramin, 2004, Tanzania Strategic Country Gender Assessment (Washington D.C.: World Bank).

Blackden, Mark, and Mary Hallward-Driemeier, 2013, "Ready to Bloom?” Finance \& Development, Vol. 50, pp. 16-19.

Budlender, Debbie, 2000, “The Political Economy of Women's Budgets in the South," World Development, Vol. 28, pp. 1365-1378.

Budlender, Debbie, 2002, “A Profile of Country Activities,” in Debbie Budlender, Diane Elson, Guy Hewitt, and Tanni Mukhopadhyay (contributing eds.), Gender Budgets Make Cents (London: Commonwealth Secretariat), pp. 131-164.

Budlender, Debbie, and Guy Hewitt, eds., 2002, Gender Budgets Make More Cents: Country Studies and Good Practice (London: Commonwealth Secretariat).

Budlender, Debbie, Diane Elson, Guy Hewitt, and Tanni Mukhopadhyay, contributing editors, 2002, Gender Budgets Make Cents (London: Commonwealth Secretariat). 
Budlender, Debbie and Guy Hewitt, 2003, Engendering Budgets: A Practitioner's Guide to Understanding and Implementing Gender-Responsive Budgets (London:

Commonwealth Secretariat).

Budlender, Debbie, 2008, Statistical Evidence on Care and Non-Care Work Across Six Countries, Gender and Development Programme Paper Number 4 (Geneva: UNRISD).

Budlender, Debbie, Daniela Casale, and Imraan Valodia, 2010, "Gender Equality and Taxation in South Africa," in Caren Grown and Imraan Valodia, (eds.), Taxation and Gender Equity (New York: Routledge), pp. 206-232.

Burn, Nalini, 2016, unpublished manuscript on gender budgeting in sub-Saharan Africa.

Byanyima, Winnie, 2003, "Politics, Good Governance and Gender: The Experience of Three African Countries," paper presented at the Fifth Global Forum on Re-Inventing Government, Mexico, November.

Center for International Forestry Research (CIFOR), 2014, Gender Equality as a Pathway for Sustainable Development: Lessons learned in Eastern and Southern Africa.

Cuberes, David, and Marc Teignier, 2014, "Gender Inequality and Economic Growth: A Critical Review," Journal of International Development, Vol. 26, pp. 260-76.

Cuberes, David, and Marc Teignier, 2014, "Aggregate Costs of Gender Gaps in the Labor Market: A Quantitative Estimate," UB Economics Working Papers, E14/308.

Department of Women, Children, and People with Disabilities, South Africa, 2014, South Africa's Beijing +20 Report (Pretoria: Republic of South Africa).

DFID, 2015, "Project Completion Review," report on the UN Joint Programme on Gender Equality_Uganda, unpublished.

Dietl, Susanne, Luise Gubitzer, Consolata Kabonesa, and Elisabeth Klatzer, 2014, "The Budget Process in Uganda: Entry Points for Gender and Gender Responsive Budgeting in the Budget Process in Uganda," Working Paper, Austrian Development Cooperation.

DSD, SASSA and UNICEF, 2012, The South African Child Support Grant Impact Assessment: Evidence from a survey of children, adolescents and their households (Pretoria: UNICEF).

Duflo, Esther, 2012, "Women Empowerment and Economic Development," Journal of Economic Literature, Vol. 50, pp. 1051-79. 
Ebeke, Christian, and Helene Ehrhart, 2013, Tax Revenue Instability in Sub-Saharan Africa: Consequences and Remedies (Paris: Banque De France).

Elborgh-Woytek,Katrin, Monique Newiak, Kalpana Kochhar, Stefania Fabrizio, Kangni Kpodar, Philippe Wingender, Benedict J. Clements, and Gerd Schwartz, 2013, "Women, Work, and the Economy: Macroeconomic Gains from Gender Equity," Staff Discussion Notes 13/10 (Washington: International Monetary Fund).

Elson, Diane, 2006, Budgeting for Women's Rights: Monitoring Government Budgets for Compliance with CEDAW (New York: UNIFEM).

Fontana, Marzia, and Luisa Natali, 2008, Gendered Patterns of Time Use in Tanzania: Public Investment in Infrastructure Can Help (Washington, D.C.: IFPRI).

Gender Monitoring Office, 2011, Key Gender Indicators and Baseline in Four Sectors: Governance, Agriculture, Infrastructure, and Private Sector (Rwanda, GMO).

Gender Monitoring Office, 2014, Gender Monitoring Office Annual Report 2013-2014 (Rwanda, GMO).

Gonzales, Christian, Sonali Jain-Chandra, Kalpana Kochhar, Monique Newiak, and Tlek Zeinullayev, 2015, "Catalyst for Change: Empowering Women and Tackling Income Inequality,” IMF Staff Discussion Note, SDN 15/20 (Washington, DC: IMF).

Hakura, Dalia, Christine Dieterich, et al. 2015, "Inequality and Economic Outcomes in SubSaharan Africa," African Department Regional Economic Outlook: Dealing with the Gathering Clouds," pp. 55-76.

Holvoet, Nathalie, and Liesbeth Inberg, 2013, "Multiple Pathways to Gender-Sensitive Budget Support in the Education Sector Analyzing the Effectiveness of SexDisaggregated Indicators in Performance Assessment Frameworks and Gender Working Groups in (education) Budget Support to Sub-Saharan Africa Countries," UNU-World Institute for Development Economics Research, Working Paper-No. 2013/105.

Holvoet, Nathalie, and Liesbeth Inberg, 2014, "Gender Responsive Budgeting and the Aid Effectiveness Agenda: Experiences from Mozambique," Journal of International Women's Studies, Vol. 15, pp. 61-79.

Ibraimo, Maimuna, 2003, “The Gender Dimension of Mozambique’s Budget—An Assessment Report,” UNIFEM Southern Africa Regional Office.

International Monetary Fund (IMF), 2013a, Regional Economic Outlook: Sub-Saharan Africa (Washington, DC: IMF). 
International Monetary Fund (IMF), 2013b, Mali, Poverty Reduction Strategy Paper (Washington, DC: IMF).

International Monetary Fund (IMF), 2014a, South Africa, IMF Country Report No. 14/338 (Washington, DC: IMF).

International Monetary Fund (IMF), 2014b, Rwanda, IMF Country Report No. 14/343 (Washington, DC: IMF).

International Monetary Fund (IMF), 2014c, United Republic of Tanzania, IMF Country Report No. 14/120 (Washington, DC: IMF).

International Monetary Fund (IMF), 2015a, Fiscal Policy and Long-Term Growth, IMF Policy Paper (Washington, DC: IMF).

International Monetary Fund (IMF), 2015b, Uganda, IMF Country Report No. 15/175 (Washington DC: IMF).

Kabeer, Naila, and Luisa Natali, 2013, "Gender Equality and Economic Growth: Is There a Win-Win?” IDS Working Paper, Volume 2013, No. 417 (Brighton: Institute of Development Studies).

Kakande, Margaret, 2007, "Financing for Gender Equality and Empowerment of Women: Uganda's Experience,” EGM/FFGE/2007/E.8 (New York: United Nations).

Keen, Michael, and Mario Mansour, 2009, "Revenue Mobilization in Sub-Saharan Africa: Challenges from Globalization," International Monetary Fund Working Paper 09/157 (Washington, DC: IMF).

Klasen, Stephan, and Francesca Lamanna, 2009, “The Impact of Gender Inequality in Education and Employment on Economic Growth: New Evidence for a Panel of Countries," Feminist Economics, Vol. 3, pp. 91-143.

Klos, Stefan, and Monique Newiak, 2015, "Income Inequality, Gender Inequality, and Growth in the WAEMU, West African Economic and Monetary Union: Selected Issues, IMF Country Report 16/98, pp. 46-57.

Kolovich, Lisa, and Sakina Shibuya, 2016, "Middle East and Central Asia: A Survey of Gender Budgeting Efforts,” IMF Working Paper 16/151 (Washington, DC: IMF).

Kytola, Liisa, 2008, Integrating Gender Responsive Budgeting into the Aid Effectiveness Agenda: Tanzania Country Report (New York: UNIFEM).

Lakwo, Alfred, 2009, "Making Decentralization Work for Women in Uganda," African Studies Collection, Vol.16 (Leiden: African Studies Centre). 
Manyeruke, Charity, and Shakespear Hamausw, 2013, "Feminisation of Gender Budgeting: An Uphill Task for Zimbabwe,” EASSRR, Vol. 29, pp. 77-105.

McKinsey Global Institute, 2015, The Power of Parity: How Advancing Women's Equality Can Add \$12 Trillion to Global Growth, September (McKinsey \& Company

Mhina, Edward Hiza, 2007, Financing for Gender Equality and the Empowerment of Women: Experiences from Tanzania.

Ministry of Community Development, Gender, and Children (MCDGC), and Ministry of Empowerment, Social Welfare, Youth, Women, and Children Development (MESWYWCD), Tanzania, 2014, Country Report on the Review and Progress Made and Challenges Encountered in Implementation of the Beijing Declaration and Platform for Action and Outcomes of the Twenty Third Special Session of the General Assembly - Beijing +20 (Dar es Salaam and Zanzibar).

Ministry of Finance and Economic Development (MOFED) and Ministry of Education (MOE), Ethiopia, 2009, Guidelines for Gender Sensitive Budgeting in Girls' Education (Ethiopia).

Ministry of Finance and Economic Planning (MINECOFIN), Rwanda, 2009, Budget Call Circular for 2009 Budget Preparation (Rwanda).

Ministry of Finance and Economic Planning (MINECOFIN), Rwanda, 2011, Gender Responsive Budgeting Programme in Rwanda, 2008-2010 (Rwanda).

Ministry of Gender, Labour and Social Development/Ministry of Local Government, Uganda, 2005, Gender Budgeting Guidelines and Analytical Tools for Lower Local Governments (Kampala).

Ministry of Gender, Labour and Social Development, Uganda, 2014, National Report on Implementation of the Beijing Platform for Action (1995) and the Outcome of the Twenty Third Special Session of the United Nations General Assembly (2000) (Kampala).

Mirwobe, Siringi Elijah, 2013, "Macro, Mezzo and Micro-Level Analysis of GenderResponsive Budgeting in Rwanda," Journal of Development and Agricultural Economics, Vol. 5, pp. 71-83.

Motsepe Foundation, 2013, Doing More with Less: A South African Gender Budget Analysis for Health, Agriculture, Forestry and Fisheries, Energy and Trade and Industry (2012/2012).

Mugisha Baine, Euzobia, M., 2013, A Terminal Evaluation Report for the Project 'Gender Budgeting for Northern Uganda, Recovery, Reconstruction and Development.' (New York: UNDP). 
Mukunda, Julius, 2011, Progress Towards Achieving Gender Responsive Budget in Rwanda: A CSO Response to Sectoral GB Statements for the FY 2011/12.

National Planning Authority (NPA), Uganda 2015, Second National Development Plan (NDP II) 2015/16 - 2019/20 (Kampala).

Ngwenya, Lindiwe, 2013, The Zimbabwe Gender Budgeting Experience-Mainstreaming Gender in Public Finance Management (Zimbabwe: Zimbabwe Women's Resource Centre and Network).

Organization for Economic Cooperation and Development, 2005, Paris Declaration on Aid Effectiveness (Paris: OECD).

Organization for Economic Cooperation and Development, 2012, Closing the Gender Gap: Act Now (Paris: OECD).

Organization for Economic Cooperation and Development, 2014, Financing the Unfinished Business of Gender and Women's Rights: Priorities for the Post-2015 Framework: Technical Brief (Paris: OECD).

OECD/UNDP, 2014, Making Development Co-operation More Effective: 2014 Progress Report (Paris: OECD).

Quinn, Sheila, 2016, “Europe: A Survey of Gender Budgeting Efforts,” IMF Working Paper (Washington, DC: IMF).

Republic of Rwanda, 2014, Report on the Implementation of the Beijing Declaration and Platform for Action (1995) and the Outcomes of the Twenty-Third Special Session of the General Assembly (2000) (Kigali).

Rusimbi, Mary, 2002, "Mainstreaming Gender into Policy, Planning and Budgeting in Tanzania," in Karen Judd (ed.), Gender Budget Initiatives: Strategies, Concepts and Experiences (New York: UNIFEM), pp. 119-125.

Rusimbi, Mary, and Anna Kikwa, 2008, Research Paper on Just Budgets: Increasing Accountability and Effectiveness Through Gender Budget Analysis in Tanzania (London: One World Action).

Seguino, Stephanie, and Maureen Were, 2014, "Gendered Perspectives on Economic Growth and Development in Sub-Saharan Africa, WIDER Working Paper 2014/056, United Nations University. 
Sharp, Rhonda, 2003, Budgeting for Equity: Gender Budget Initiatives Within a Framework of Performance Oriented Budgeting (New York: UNIFEM).

Southern African Development Community (SADC), 2008, SADC Protocol on Gender and Development.

Southern African Development Community (SADC), 2014, SADC Guidelines on Gender Responsive Budgeting.

South African delegation, "GRBI Profile Brief and Template," International Conference of Gender Budgeting in Marrakech in November 2012, organized by the Ministry of Economy and Finance of Morocco.

South African, Social Security Agency (SASSA), various years, A Statistical Summary of Social Grants in South Africa (Pretoria: SASSA).

Ssewakiryanga, Richard, 2005, The Politics of Revisiting the PEAP/PRSP in Uganda, Presented at the International Conference on Political Dimensions of Poverty Reduction, Lusaka, Zambia.

Ssewanyana, Sarah, Lawrence Bategka, Madina Guloba, and Julius Kiiza, 2010, "Gender Equality and Tazation in Uganda," in Caren Grown and Imraan Valodia, (eds.), Taxation and Gender Equity (Abingdon, Oxon, and New York: Routledge), pp. 233260.

Stotsky, Janet G., 1997, “Gender Bias in Tax Systems,” Tax Notes International (June 9), pp. 1913-23.

, Sakina Shibuya, Lisa Kolovich, and Suhaib Kebhaj, 2016, "Trends in Women's Advancement and Gender Equality," International Monetary Fund Working Paper 16/21 (Washington, DC: IMF).

Stotsky, Janet G., 2016, “Gender Budgeting: Fiscal Context and Current Outcomes,” IMF Working Paper 16/149 (Washington, DC: IMF).

Tanzarn, Nite, 2008, Integrating Gender Responsive Budgeting into the Aid Effectiveness Agenda: Uganda Country Report (New York: UNIFEM).

Uganda Bureau of Statistics (UBOS), 2014, Uganda National Household Survey 2012/2013 (Kampala: UBOS). 
United Nations Development Program, 2011, Gender Budget Project for Northern Uganda Recovery, Reconstruction and Development (New York: UNDP).

UNIFEM, 2009, UNIFEM's Work on Gender Responsive Budgeting: Overview, Evaluation Unit (NewYork: UNIFEM)

UNIFEM, 2009, Gender-Responsive Budgeting Program: Mozambique, Evaluation Unit (New York: UNIFEM).

UNIFEM, 2009, Gender-Responsive Budgeting Program: Senegal, Evaluation Unit (New York: UNIFEM).

United Nations, 1995, "Platform for Action," Fourth World Congress on Women. http://www.un.org/womenwatch/daw/beijing/platform/plat2.htm.

United Nations, 2015, Transforming our World: The 2030 Agenda for Sustainable Development, A/RES/70/1.

United Nations Economic Commission for Africa, 2015 (UNECA), Addis Ababa Declaration on Accelerating the Implementation of the Beijing Platform for Action: Towards a Transformational Change for Women and Girls in Africa (Addis Ababa: United Nations).

United Nations Joint Programme on Gender Equality (UNJPGE)—Uganda, 2014, Annual Narrative Report (New York: UN).

UN Women, 2014, National Report on the Implementation of the Beijing Declaration and Platform for Action: The Federal Democratic Republic of Ethiopia (New York: UN).

UN Women, UNEP, UNDP, and World Bank, 2015, Cost of the Gender Gap in Agriculture Productivity in Malawi, Tanzania, and Uganda (New York and Washington, DC: UN and World Bank).

Verdickt, Magda, 2009, Case Study: Gender-Responsive Budgeting in Mauritius (New York: UNDP).

World Bank, 2005, Uganda: From Periphery to Center, Strategic Country Gender Assessment (Washington, DC: World Bank).

Youhou, Djedje Hermann, 2015, "In Search of Fiscal Space in Africa: The Role of the Quality of Government Spending," Etudes et Documents, No. 27, CERDI. 


\section{Appendix A. Gender Budgeting in Sub-Saharan Africa Data Template}

\begin{tabular}{|c|c|c|c|c|}
\hline & Rwanda & South Africa & Tanzania & Uganda \\
\hline \multicolumn{5}{|l|}{ ORIGINS } \\
\hline Does the government have a gender budgeting initiative & Yes & Yes & Yes & Yes \\
\hline If yes, start year & 2002 & 1998-1999 & 1999 & $2004 / 2005$ \\
\hline If any, end year & \multicolumn{3}{|c|}{ ended; year unknown } & \\
\hline Supported by international organizations or bilateral aid agencies & Yes & Yes & Yes & Yes \\
\hline Tied to MDGs or national development plan or gender equality strategy & Yes & No & Yes & Yes \\
\hline \multicolumn{5}{|l|}{ SELECTED COMPONENTS OF FISCAL POLICY } \\
\hline Focus on spending & Yes & Yes & Yes & Yes \\
\hline Spending focus on key human development (education and health) & Yes & Yes & Yes & Yes \\
\hline Spending focus on physical infrastructure (transport, water, electricity, and energy) & Yes & Yes & Yes & Yes \\
\hline Spending focus on justice and security (violence against women, judicial assistance) & Yes & Yes & No & Yes \\
\hline Spending focus on jobs, entrepreneurship, wages etc & Yes & Yes & Yes & Yes \\
\hline Structural reforms in spending (subsidies, transfers, incentive or distributional objectives) & Yes & Yes & Yes & Yes \\
\hline Focus on revenue & No & Yes & Yes & Yes \\
\hline Personal income tax focus & No & Yes & No & No \\
\hline Other tax focus, including general or selective sales and trade & No & Yes & Yes & Yes \\
\hline \multicolumn{5}{|l|}{ INDICATORS TO PLACE GENDER BUDGETING IN THE FISCAL PROCESS } \\
\hline Broad statement of goals of Minister of Finance & No & No & No & No \\
\hline Gender budgeting statement in budget documentation & Yes & Yes & Yes & Yes \\
\hline Gender budgeting circular or related to instruct the bureaucracy & Yes & No & Yes & Yes \\
\hline Gender budgeting in planning and programming & Yes & Yes & Yes & Yes \\
\hline Gender budgeting outcome report or audit & Yes & No & No & Yes \\
\hline Explicit reporting on gender equality spending & Yes & No & No & Yes \\
\hline \multicolumn{5}{|l|}{ LEGAL BASIS } \\
\hline Gender budgeting has constitutional standing & Yes & No & No & No \\
\hline Gender budgeting is incorporated in organic budget or other finance laws & Yes & No & No & Yes \\
\hline
\end{tabular}




\begin{tabular}{|c|c|c|c|c|}
\hline & Rwanda & South Africa & Tanzania & Uganda \\
\hline \multicolumn{5}{|l|}{ ROLE OF GOVERNMENT } \\
\hline Ministry of Finance lead entity & Yes & Yes & Yes & Yes \\
\hline Other ministries play consequential role and which & $\begin{array}{c}\text { Yes; Ministry of } \\
\text { Gender and } \\
\text { Family } \\
\text { Promotion; } \\
\text { Ministry of } \\
\text { Finance; } \\
\text { Gender } \\
\text { Monotoring } \\
\text { Office }\end{array}$ & $\begin{array}{c}\text { Yes; The } \\
\text { National } \\
\text { Department of } \\
\text { Finance } \\
\text { (National } \\
\text { Treasury); The } \\
\text { Ministry of } \\
\text { Women, } \\
\text { Children, and } \\
\text { People with } \\
\text { Disabilities }\end{array}$ & $\begin{array}{l}\text { Yes; Ministry of } \\
\text { Community } \\
\text { Development, } \\
\text { Gender and } \\
\text { Children; The } \\
\text { Ministry of } \\
\text { Finance }\end{array}$ & $\begin{array}{l}\text { Yes; Ministry of } \\
\text { Finance, } \\
\text { Planning, and } \\
\text { Economic } \\
\text { Development; } \\
\text { The Ministry of } \\
\text { Gender, Labour } \\
\text { and Social } \\
\text { Development; } \\
\text { The Ministry of } \\
\text { Local } \\
\text { Government; } \\
\text { The ministry of } \\
\text { Education }\end{array}$ \\
\hline Subnational government & Yes & Yes & Yes & Yes \\
\hline \multicolumn{5}{|l|}{ ROLE OF CIVIL SOCIETY } \\
\hline Significant encouragement or participation of civil society & Yes & Yes & Yes & Yes \\
\hline
\end{tabular}

